\title{
Variability in above- and belowground carbon stocks in a Siberian larch watershed
}

\author{
Elizabeth E. Webb ${ }^{1}$, Kathryn Heard ${ }^{2}$, Susan M. Natali ${ }^{1}$, Andrew G. Bunn ${ }^{3}$, Heather D. Alexander ${ }^{4}$ Logan T. Berner $^{5}$, \\ Alexander Kholodov ${ }^{6,7}$, Michael M. Loranty ${ }^{8}$, John D. Schade ${ }^{1}$, Valentin Spektor ${ }^{9}$, and Nikita Zimov ${ }^{10}$ \\ ${ }^{1}$ Woods Hole Research Center, 149 Woods Hole Road, Falmouth, MA 02540, USA \\ ${ }^{2}$ Western Washington University, 516 High Street, Bellingham, WA 98225, USA \\ ${ }^{3}$ Department of Environmental Science, Western Washington University, 516 High Street, Bellingham, WA 98225, USA \\ ${ }^{4}$ Department of Forestry, Forest and Wildlife Research Center, Mississippi State University, MS 39762, USA \\ ${ }^{5}$ School of Informatics, Computing, and Cyber Systems, Northern Arizona University, Flagstaff, AZ 86011, USA \\ ${ }^{6}$ University of Alaska, 903 Koyukuk Dr., Fairbanks, AK 99775, USA \\ ${ }^{7}$ Institute of Physical-Chemical and Biological Problems of Soil Science RAS, 2 Institutskaya str., Pushchino, Russia \\ ${ }^{8}$ Department of Geography, Colgate University, 13 Oak Dr, Hamilton, NY 13346, USA \\ ${ }^{9}$ Melnikov Permafrost Institute, Siberian Branch of the Russian Academy of Sciences, Yakutsk, Russia \\ ${ }^{10}$ Northeast Science Station, Chersky, Russia
}

Correspondence to: Susan M. Natali (snatali@whrc.org)

Received: 14 March 2017 - Discussion started: 3 April 2017

Revised: 9 August 2017 - Accepted: 10 August 2017 - Published: 26 September 2017

\begin{abstract}
Permafrost soils store between 1330 and $1580 \mathrm{Pg}$ carbon $(\mathrm{C})$, which is 3 times the amount of $\mathrm{C}$ in global vegetation, almost twice the amount of $\mathrm{C}$ in the atmosphere, and half of the global soil organic $\mathrm{C}$ pool. Despite the massive amount of $\mathrm{C}$ in permafrost, estimates of soil $\mathrm{C}$ storage in the high-latitude permafrost region are highly uncertain, primarily due to undersampling at all spatial scales; circumpolar soil $\mathrm{C}$ estimates lack sufficient continental spatial diversity, regional intensity, and replication at the field-site level. Siberian forests are particularly undersampled, yet the larch forests that dominate this region may store more than twice as much soil $\mathrm{C}$ as all other boreal forest types in the continuous permafrost zone combined. Here we present above- and belowground $\mathrm{C}$ stocks from 20 sites representing a gradient of stand age and structure in a larch watershed of the Kolyma River, near Chersky, Sakha Republic, Russia. We found that the majority of $\mathrm{C}$ stored in the top $1 \mathrm{~m}$ of the watershed was stored belowground ( $92 \%$ ), with $19 \%$ in the top $10 \mathrm{~cm}$ of soil and $40 \%$ in the top $30 \mathrm{~cm}$. Carbon was more variable in surface soils $(10 \mathrm{~cm}$; coefficient of variation $(\mathrm{CV})=0.35$ between stands) than in the top $30 \mathrm{~cm}(\mathrm{CV}=0.14)$ or soil profile to $1 \mathrm{~m}(\mathrm{CV}=0.20)$. Combined active-layer and deep frozen deposits (surface $-15 \mathrm{~m}$ ) contained $205 \mathrm{~kg} \mathrm{C} \mathrm{m}^{-2}$
\end{abstract}

(yedoma, non-ice wedge) and $331 \mathrm{~kg} \mathrm{C} \mathrm{m}^{-2}$ (alas), which, even when accounting for landscape-level ice content, is an order of magnitude more $\mathrm{C}$ than that stored in the top meter of soil and 2 orders of magnitude more $\mathrm{C}$ than in aboveground biomass. Aboveground biomass was composed of primarily larch $(53 \%)$ but also included understory vegetation $(30 \%)$, woody debris $(11 \%)$ and snag $(6 \%)$ biomass. While aboveground biomass contained relatively little $(8 \%)$ of the $\mathrm{C}$ stocks in the watershed, aboveground processes were linked to thaw depth and belowground $\mathrm{C}$ storage. Thaw depth was negatively related to stand age, and soil $\mathrm{C}$ density (top $10 \mathrm{~cm}$ ) was positively related to soil moisture and negatively related to moss and lichen cover. These results suggest that, as the climate warms, changes in stand age and structure may be as important as direct climate effects on belowground environmental conditions and permafrost $\mathrm{C}$ vulnerability. 


\section{Introduction}

Boreal forests cover roughly $22 \%$ of the earth's terrestrial landscape (Chapin et al., 2000) and account for approximately $9 \%$ of the global vegetation carbon (C) stock (Carvalhais et al., 2014). Most of the $\mathrm{C}$ in boreal forests, however, is stored in the soil (Pan et al., 2011), where cold and wet conditions have limited microbial decomposition; as a result, $\mathrm{C}$ has accumulated over the past several millennia (Hobbie et al., 2000; Trumbore and Harden, 1997). Recent estimates suggest that continuous and discontinuous permafrost in the boreal region store around $137 \mathrm{Pg}$, or $40 \%$ of near-surface permafrost $(<1 \mathrm{~m}) \mathrm{C}$ (Loranty et al., 2016). Despite the massive amount of $\mathrm{C}$ present in the boreal region, the quantity of $\mathrm{C}$ stored here and the magnitude of the change in $\mathrm{C}$ stocks that will result from climate change is one of the least understood carbon-climate feedbacks (Schuur et al., 2015).

Over the past 50 years, air temperatures in the Arctic have risen nearly twice the global average as a result of climate change (Christensen et al., 2013), and this accelerated rate of warming means that the vast amount of $\mathrm{C}$ stored in high-latitude systems is vulnerable to loss to the atmosphere (Koven et al., 2015; Schuur et al., 2015). The amount of C released as a result of thaw will be highly dependent on concurrent changes in topography and hydrology (Liljedahl et al., 2016; Schneider Von Deimling et al., 2015), vegetation (Guay et al., 2014; Sturm et al., 2005), fire regimes (Berner et al., 2012; Kasischke and Turetsky, 2006; Rogers et al., 2015; Soja et al., 2007), nutrient availability (Mack et al., 2004; Salmon et al., 2016), and soil organic C lability (Harden et al., 2012; Schädel et al., 2014). Yet despite the vulnerability of permafrost soils to increased thaw and $\mathrm{C}$ release due to climate change, there is a lack of data quantifying the $\mathrm{C}$ stocks at northern latitudes compared to other regions.

Permafrost $\mathrm{C}$ pool estimates tend to be dominated by sites located in Alaska or western Russia, with very few data points from the Russian low Arctic or Canadian high Arctic (Hugelius et al., 2014; Tarnocai et al., 2009). As a result, many regions are under-represented in circumpolar permafrost C estimates (Hugelius et al., 2014; Johnson et al., 2011; Mishra et al., 2013; Tarnocai et al., 2009). Even in Alaska, which is one of the most densely sampled Arctic subregions, Mishra and Riley (2012) found that the current sample distribution is insufficient to characterize regional soil organic C (SOC) stocks fully because of SOC variation across vegetation types, topography, and parent material. Furthermore, permafrost regions are characterized by high heterogeneity in soil $\mathrm{C}$ stocks due to variability in soil-forming factors (Vitharana et al., 2017) and at small spatial scales due to cryogenic processes (i.e., cryoturbation at the sub-meter scale). As a result, sampling at higher spatial resolution may provide more accurate estimates of soil $\mathrm{C}$ stocks (Johnson et al., 2011; Tarnocai et al., 2009). Therefore, understanding variation in soil properties at the meter scale is critical for reducing uncertainty in estimates of current and future permafrost C pools (Beer, 2016).

Pleistocene-aged $\mathrm{C}$ and ice-rich permafrost (i.e., yedoma) deposits occur across Siberia and Alaska (Strauss et al., 2013) and are particularly important for regional soil C estimates. Yedoma deposits froze relatively quickly in geologic history (Schirrmeister et al., 2011; Zimov et al., 2006); as a consequence, these deep deposits (on average $25 \mathrm{~m}$; Zimov et al., 2006) are $C$ rich compared to some other permafrost soils (Strauss et al., 2013; Zimov et al., 2006). Approximately $30 \%$ of high-latitude permafrost $C$ is found in these yedoma deposits, even though they comprise only $7 \%$ of the landscape (Walter Anthony et al., 2014). However, due to limited sampling of deep ( $>3 \mathrm{~m}$ ) permafrost, establishing how much $\mathrm{C}$ is in these deposits is difficult, leading to high uncertainty in estimates of soil $\mathrm{C}$ pools in yedoma deposits (Strauss et al., 2013; Walter Anthony et al., 2014).

While vegetation stores a relatively small portion of the $\mathrm{C}$ pool in boreal forests (approximately $20 \%$; Pan et al., 2011), it plays a crucial role in local and global $\mathrm{C}$ cycling, and many future changes in $\mathrm{C}$ fluxes in this biome will likely occur as a result of changes in vegetation (Elmendorf et al., 2012; Euskirchen et al., 2009; Myers-Smith et al., 2015; Swann et al., 2010). With increased temperatures, boreal forests are susceptible to insect invasions (Berg et al., 2006; Kurz et al., 2008), moisture stress (Beck et al., 2011; Trahan and Schubert, 2016; Walker et al., 2015), tree line advance and retrogression (Lloyd, 2005; Pearson et al., 2013), and more frequent forest fires (Kasischke and Turetsky, 2006; Rogers et al., 2015; Soja et al., 2007), which all have the potential to alter $\mathrm{C}$ cycling significantly in the region. Importantly, climatechange-driven alterations in forest cover, composition, and structure will influence regional energy balance through impacts on surface albedo, evapotranspiration, and ground insulation, which will in turn affect ground thaw and soil C cycling (Chapin et al., 2005; Euskirchen et al., 2009; Fisher et al., 2016; Jean and Payette, 2014; Loranty et al., 2014).

However, the aboveground processes that regulate $\mathrm{C}$ dynamics are not homogenous throughout the boreal biome (Goetz et al., 2007). For example, the fire regimes of larch (Larix spp.) and pine (Pinus sylvestris) forests in Siberia are typically dominated by low- to medium-intensity fires, whereas dark coniferous forests common in Alaska and Canada are characterized by fires higher in intensity and severity (Rogers et al., 2015; Soja et al., 2006, 2007; Tautenhahn et al., 2016). The dynamics of larch forests are particularly important, as they store more than twice the amount of SOC of all other boreal forest types in the continuous permafrost zone combined (Loranty et al., 2016). Despite this, larch forests in Siberia are notably understudied; indeed, the estimate of C stored in Russian forests is the least well constrained of all forest systems globally (Shuman et al., 2013).

In this study, we aim to reduce the uncertainty of regional $\mathrm{C}$ estimates by providing a comprehensive assessment of vegetation, active-layer, and permafrost $\mathrm{C}$ stocks 
in the Kolyma River watershed in northeast Siberia, Russia. We present aboveground and belowground (to $1 \mathrm{~m}$ ) $\mathrm{C}$ stocks from data collected from 20 sites across the watershed along with deep permafrost $\mathrm{C}$ pools to $15 \mathrm{~m}$ depth from a yedoma deposit and an alas (thermokarst depression). We compare variation in soil $\mathrm{C}$ pools at meter to kilometer scales in order to quantify the variability of permafrost $\mathrm{C}$ at small spatial scales. Additionally, we examine the drivers of thaw depth and $\mathrm{C}$ density of active-layer soils to understand environmental controls over these variables across the watershed. Together, these analyses allow us to estimate $\mathrm{C}$ pools and controls over changes in these pools that will likely occur with climate change.

\section{Methods}

\subsection{Site description}

Our study area was a watershed ("Y4 watershed", $\sim 3 \mathrm{~km}^{2}$; Fig. 1) located within the Kolyma River basin, which is the largest river basin $\left(650000 \mathrm{~km}^{2}\right)$ completely underlain by continuous permafrost (Holmes et al., 2012). The Y4 watershed is located near Chersky, Sakha Republic, Russia, approximately $130 \mathrm{~km}$ south of the Arctic Ocean and is underlain by yedoma, which is widespread across the region (Grosse et al., 2013). The climate is continental with short, warm summers (July average: $12^{\circ} \mathrm{C}$ ) and long, cold winters (January average: $-33^{\circ} \mathrm{C}$ ). Annual precipitation is low $(\sim 230 \mathrm{~mm}$ ) and often occurs during summer (Chersky Meteorological Station; S. Davydov, unpublished data). Mean summer temperatures in this region increased by $1^{\circ} \mathrm{C}$ from 1938 to 2009 (Berner et al., 2013).

There are two main types of cryogenic deposits within the watershed. Upland areas are Late Pleistocene syngenetic icerich deposits of yedoma. Drained thaw lake depressions are underlain by alas consisting of lacustrine-wetland sediments in the upper pedon and taberal (i.e., yedoma that thawed in a talik) deposits in the lower part of the profile. Permafrost temperatures at $15 \mathrm{~m}$ vary from $-2.8^{\circ} \mathrm{C}$ at the hilltops with relatively thin organic layers to $-4^{\circ} \mathrm{C}$ in thermokarst depressions with thick (up to $20 \mathrm{~cm}$ ) moss and peat layers (A. Kholodov, unpublished data).

Forests in the watershed are composed of a single larch species, Larix cajanderi, with a well-developed understory of deciduous shrubs (primarily Betula nana, Salix spp., and Vaccinium uliginosum), evergreen shrubs (e.g., Vaccinium vitis-idaea, Empetrum nigrum, and Rhododendron subarcticum), forbs (e.g., Equisetum scirpoides, Pyrola spp., and Valeriana capitata), graminoids (Calamagrostis spp.), moss (e.g., Aulacomnium palustre, Dicranum spp., and Polytrichum spp.), and lichen (e.g., Cladonia spp., Peltigera aphthosa, and Flavocetraria cucullata).

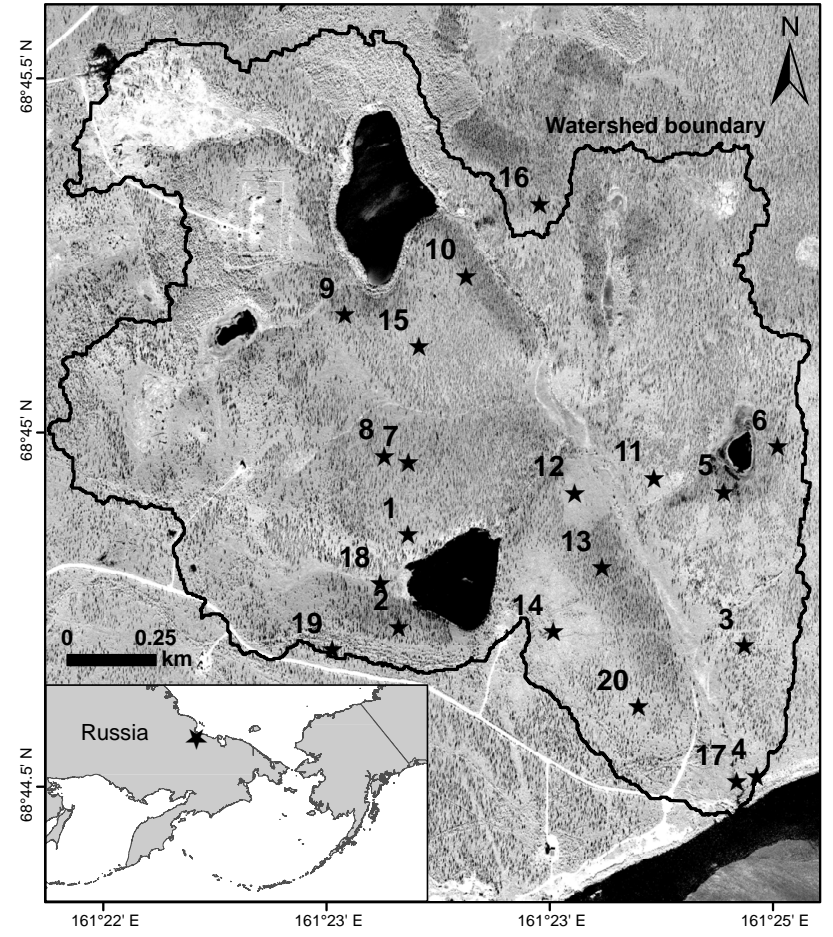

Figure 1. Location of the Y4 watershed in relation to Russia (inset) and location of the sampling sites within the Y4 catchment.

\subsection{Site selection and sampling design}

We selected 20 stands (i.e., "sites") in the Y4 watershed that spanned a range of aboveground tree biomass, as inferred from tree shadows mapped using high-resolution $(50 \mathrm{~cm})$ WorldView-1 satellite imagery (Berner et al., 2012; Fig. 1). All sites were located in forested stands except for one in a Salix-dominated riparian zone (Site 17) and another in a Sphagnum-dominated alas (Site 18; Table 1). Within each site, we established three $20 \mathrm{~m}$ long by $2 \mathrm{~m}$ wide plots, each of which was separated by $8 \mathrm{~m}$ and ran parallel to slope contours (Fig. S1 in the Supplement). In the absence of a discernable slope, transects were aligned north-south. All sampling was conducted in July 2012 and 2013 except stand age, which was sampled in 2016.

\subsection{Stand age}

To determine stand age, we collected a wood slab or core from the base ( $\sim 30 \mathrm{~cm}$ above the organic layer) of 5-10 trees sampled randomly within each stand. Wood samples were dried at $60^{\circ} \mathrm{C}$ and then sanded sequentially with finer grit sizes to obtain a smooth surface. Each sample was then scanned, and the annual growth rings were counted using WinDENDRO (Regent Instruments, Inc., Ontario, Canada). 
Table 1. Site characteristics. All sites were in forested areas except no. 17 (riparian); site no. 18 (alas) had few scattered trees located along one end of the sampling transects.

\begin{tabular}{lrrrrrr}
\hline $\begin{array}{l}\text { Site } \\
\text { number }\end{array}$ & $\begin{array}{r}\text { Latitude } \\
(\text { degrees north) }\end{array}$ & $\begin{array}{r}\text { Longitude } \\
\text { (degrees east) }\end{array}$ & $\begin{array}{r}\text { Slope } \\
\text { (degrees) }\end{array}$ & $\begin{array}{r}\text { Aspect } \\
(\text { degrees })\end{array}$ & $\begin{array}{r}\text { Summer insolation } \\
\left(\mathrm{WH} \mathrm{m}^{-2}\right)\end{array}$ & $\begin{array}{r}\text { Stand age } \\
(\text { years })\end{array}$ \\
\hline 1 & 68.74747 & 161.38988 & 5 & 160 & 4507 & 155 \\
2 & 68.74529 & 161.38908 & 10 & 8 & 3950 & 167 \\
3 & 68.74472 & 161.41486 & 14 & 249 & 4399 & 203 \\
4 & 68.74164 & 161.41562 & 9 & 245 & 4409 & 23 \\
5 & 68.74834 & 161.41350 & 10 & 357 & 3954 & 218 \\
6 & 68.74939 & 161.41759 & 8 & 225 & 4509 & 205 \\
7 & 68.74915 & 161.39000 & 5 & 57 & 4239 & 155 \\
8 & 68.74932 & 161.38820 & 7 & 36 & 4132 & 208 \\
9 & 68.75267 & 161.38544 & 8 & 340 & 4038 & 202 \\
10 & 68.75352 & 161.39455 & 16 & 72 & 4008 & 211 \\
11 & 68.74869 & 161.40834 & 10 & 222 & 4533 & 123 \\
12 & 68.74837 & 161.40237 & 10 & 63 & 3121 & 71 \\
13 & 68.74660 & 161.40433 & 17 & 61 & 4361 & 40 \\
14 & 68.74513 & 161.40063 & 1 & 103 & 4410 & 221 \\
15 & 68.75188 & 161.39095 & 3 & 237 & 4307 & 200 \\
16 & 68.75519 & 161.40013 & 3 & 294 & 4479 & - \\
17 & 68.74152 & 161.41411 & 8 & 225 & 4314 & - \\
18 & 68.74632 & 161.38776 & 3 & 84 & 4231 & 26 \\
19 & 68.74479 & 161.38410 & 6 & 61 & 4429 & - \\
20 & 68.74333 & 161.40688 & 5 & 124 & & 40 \\
\hline
\end{tabular}

\subsection{Solar insolation and slope}

Slope and aspect at each site were determined from a $4 \mathrm{~m}$ resolution digital elevation model of the watershed created by the Polar Geospatial Center (http://www.pgc.umn.edu/) using stereopairs of WorldView imagery. Solar insolation was estimated using the Solar Radiation analyses toolset in ArcGIS version 10 (ESRI, Redlands, CA, USA). The toolset used variability in the orientation (slope and aspect) to calculate direct and diffuse radiation for each pixel of the elevation model in the Y4 watershed using viewshed algorithms (Fu and Rich, 2002; Rich et al., 1994). We report total insolation on the summer solstice for each pixel.

\subsection{Aboveground biomass}

We measured diameter at breast height (DBH; $1.4 \mathrm{~m}$ height) or basal diameter (BD; $<1.4 \mathrm{~m}$ height) of all trees and snags (i.e., dead trees standing $\geq 45^{\circ}$ to the forest floor) within each $40 \mathrm{~m}^{2}$ plot $\left(n=3 \mathrm{site}^{-1}\right)$. Live and dead aboveground tree biomass were determined based on allometric equations developed from $L$. cajanderi trees harvested near Chersky (Alexander et al., 2012). Tree biomass was converted to $\mathrm{C}$ mass using a $\mathrm{C}$ concentration of $46 \%$ for foliage (live trees only), $47 \%$ for stemwood/bark and snag, and $48 \%$ for branches (Alexander et al., 2012).

We estimated understory percent cover in six $1 \mathrm{~m}^{2}$ subplots at each site; subplots were placed at both ends of each of the three plots (at 0 and $20 \mathrm{~m}$; Fig. S1). Understory vegetation was sorted into functional types, which included shrub (evergreen and deciduous), herbs (forb and graminoids), moss, lichen, and other (litter, woody debris, and bare ground). At each site, understory vascular plant biomass was determined in three $0.25 \mathrm{~m}^{2}$ quadrats, each of which was located within one of the percent cover plots. We measured basal diameter of tall deciduous shrubs (Alnus spp., B. nana, and Salix spp.) and used published allometric relationships to derive biomass (Berner et al., 2015). All remaining vascular plants were harvested and dried at $60^{\circ} \mathrm{C}$ for $48 \mathrm{~h}$ for dry-mass determination. We converted live understory biomass values to $\mathrm{C}$ pools by multiplying biomass by $48 \% \mathrm{C}$ content.

Following the line-intercept method for measuring woody debris (Brown, 1974), we set a $20 \mathrm{~m}$ transect along the middle of each plot and counted the number of times woody debris intercepted the transect for class I fine woody debris (FWD; 0.0-0.49 cm diameter) and class II FWD (0.5$0.99 \mathrm{~cm})$ along the first $2 \mathrm{~m}$; class III FWD $(1.0-2.99 \mathrm{~cm})$ along the first $10 \mathrm{~m}$; and classes IV FWD $(3.0-4.99 \mathrm{~cm})$ and V FWD $(5.0-6.99 \mathrm{~cm})$, and downed coarse woody debris (CWD; $>7 \mathrm{~cm}$ diameter) along the entire $20 \mathrm{~m}$ length. We calculated the mass of woody debris according to Alexander et al. (2012) using previously published multipliers for softwood boreal trees from the Northwest Territories of Canada for FWD (Nalder et al., 1997) and decay class and density values for softwood boreal tree species within Ontario, Canada, for CWD (Ter-Mikaelian et al., 2008). Mass values were converted to $\mathrm{C}$ pools based on average $\mathrm{C}$ concentration of L. cajanderi boles (47 \%). Total aboveground biomass 
(AGB) is reported as the sum of the C pools in woody debris, snags, trees, and understory biomass.

\subsection{Canopy cover and leaf area index}

We measured canopy cover under uniform, diffuse light conditions at the center of each site in four cardinal directions using a convex spherical densitometer, and leaf area index (LAI) using both hemispherical photography and an LAI-2000 Plant Canopy Analyzer (Li-COR, Nebraska, NE, USA). The LAI-2000 was placed $\sim 1 \mathrm{~m}$ above the ground at the center of each site, and LAI estimates were divided by a factor of 0.68 (Chen et al., 2005) to account for foliage clumping (Chen et al., 1997). Hemispherical photographs were taken $\sim 1 \mathrm{~m}$ off the ground using a Sigma SD15 digital reflex camera with Sigma $4.5 \mathrm{~mm}$ F2.8 EX DC circular fisheye lens. A N-S reflector was used for $\mathrm{N}$ orientation, and photographs were taken using automatic settings at the center of each of the three transects at each site. The hemispherical photographs were analyzed using HemiView software.

\subsection{Thaw depth/organic layer depth}

We measured thaw depth using a metal thaw probe every meter along a $20 \mathrm{~m}$ transect placed along the center of each plot (measured from 9 July through 3 August; does not represent maximum thaw). Organic layer depth (OLD) was measured at $5 \mathrm{~m}$ intervals along each transect by cutting through the active-layer soil with a serrated knife and visually identifying and measuring the depth to the organic-mineral boundary.

\subsection{Soil sampling and analysis}

Active-layer soils were collected from all sites. Surface permafrost soils (approximately the top $60 \mathrm{~cm}$ of frozen soil, which contained some frozen active-layer soil) were sampled at seven sites (three cores per site), and deep permafrost (15 m depth) was sampled at two sites (sites 18 and 19). We collected six active-layer samples from each site, one at each end of the $20 \mathrm{~m}$ long plots. We used a serrated knife to collect an $8 \mathrm{~cm} \times 8 \mathrm{~cm}$ sample from the organic layer and a $2 \mathrm{~cm}$ diameter manual corer to collect the top $10 \mathrm{~cm}$ of mineral soil. When less than $5 \mathrm{~cm}$ of mineral soil was thawed at the time of sampling, the mineral soil sample was excluded from analysis $(n=5)$. At the seven sites where surface permafrost was sampled, we collected mineral soil to frozen ground (average $28 \mathrm{~cm}$ thawed mineral soil depth) using a manual corer and sampled approximately $60 \mathrm{~cm}$ depth of frozen soil with a Soil Ice and Permafrost Research Experiment (SIPRE) auger (7.62 cm diameter). We collected two deep permafrost cores with a rotary drill rig (UKB-12/25, Drilling Technology Factory); one deep core was collected from a site underlain by yedoma and the other from an alas. Carbon pools presented for deep permafrost include $\mathrm{C}$ in the active layer sampled at the drilling location. Carbon pools reported for $1 \mathrm{~m}$ depth were calculated using the seven surface permafrost samples as well as the top $1 \mathrm{~m}$ of the deep core from the yedoma site. All permafrost samples were kept frozen until analyzed as described below.

Surface permafrost cores were sectioned into $10 \mathrm{~cm}$ increments. Coarse roots $(>2 \mathrm{~mm})$ were removed from all active layer and surface permafrost soils, and fine roots and organic soils were dried at $60^{\circ} \mathrm{C}$ for $48 \mathrm{~h}$, while mineral soils were dried at $105^{\circ} \mathrm{C}$ for at least $48 \mathrm{~h}$. Gravimetric water content (GWC) was determined as the ratio of soil water mass to soil dry mass and was reported as a percentage (i.e., GWC $\times 100)$. Organic matter $(\mathrm{OM})$ content was measured as the percent mass lost from dried soil after combusting for $4 \mathrm{~h}$ at $450^{\circ} \mathrm{C}$. Soil $\mathrm{C}$ content was analyzed on a subset of soils (35 of 111 organic soils; 119 of 271 active layer and surface permafrost mineral soil; and 30 of 149 deep permafrost samples) on a Costech CHN analyzer at St. Olaf College or at the University of Georgia Stable Isotope Ecology Lab. Carbon concentrations of the full set of soil samples were then modeled using a linear relationship between organic matter content and percent $\mathrm{C}$ $\left(\% \mathrm{C}=0.524 . \% \mathrm{OM}-0.575 ; R^{2}=0.96\right.$ for active-layer and surface permafrost; $\% \mathrm{C}=0.391 . \% \mathrm{OM}-0.103 ; R^{2}=0.86$ for deep permafrost samples). Carbon content of coarse roots was assumed to be $50 \%$. Sampled soils were reclassified as organic or mineral as needed ( $<1 \%$ of samples) based on soil $C$ content $(C \geq 20 \%$ for organic soils).

Bulk density (BD) was determined as the mass of dry soil per unit volume $\left(\mathrm{g} \mathrm{cm}^{-3}\right)$. Volume of active-layer soil samples was determined by measuring the ground area and depth from where the soil sample was removed. Volume of permafrost samples was quantified by water displacement. Ice volume was determined based on soil water content and assuming an ice density of $0.9167 \mathrm{~g} \mathrm{~cm}^{-3}$.

Soil C stocks at each depth increment were calculated as the product of percent $\mathrm{C}, \mathrm{BD}$, and soil depth. For the deep permafrost samples, sub-samples used for percent $\mathrm{C}$, percent $\mathrm{OM}$, and $\mathrm{BD}$ measurements were collected from adjacent depth increments; therefore, for the percent $\mathrm{C}$-percent $\mathrm{OM}$ regression and $\mathrm{C}$ pool calculations, we used adjacent depth increments or interpolated values between two adjacent depths.

\subsection{Statistical analysis}

To compare the variance in soil $\mathrm{C}$ among sites and studies, we used the coefficient of variation $(\mathrm{CV})$, which is the ratio of the standard deviation to the mean. The $\mathrm{CV}$ is independent of the unit or magnitude and can be used to compare intrasite variation (how variable the data are relative to the mean value) among sites even if the mean of the sites is vastly different. We also used percent variation, which was calculated by subtracting the minimum value from the maximum value and dividing by the maximum value.

We used a linear model to determine the relationship between canopy cover, LAI, and larch biomass, and the rela- 

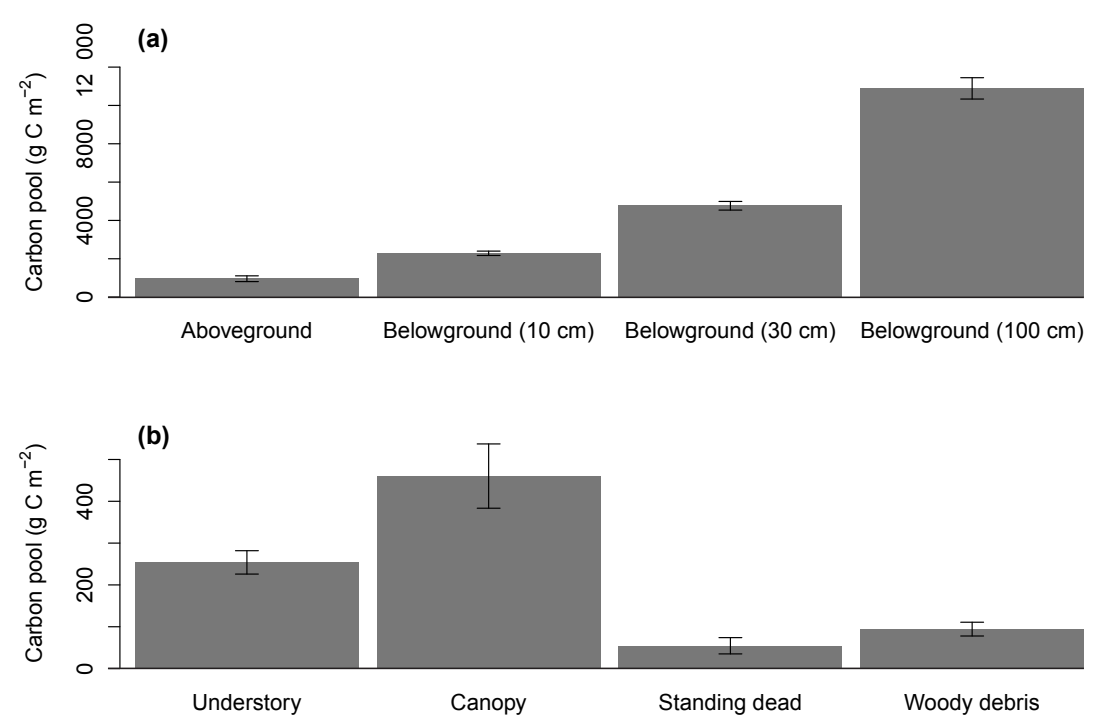

Figure 2. Average carbon density of all sites in the Y4 watershed (a: above- and belowground to $1 \mathrm{~m}$; b: aboveground only). Bars indicate standard error.

tionship between the different components of AGB. To determine potential environmental drivers of thaw depth and soil $\mathrm{C}$, we fit a mixed-effects linear model using the nlme package in R (Pinherio et al., 2013), using average plot-level data (three per site) as a replicate for each site. The fixed effects were the environmental variables, and the random effect was the nested study design (plots within sites). Both thaw depth and soil $\mathrm{C}$ were log-transformed to meet the assumption of normality. After collinear explanatory variables were removed from analysis using a variance inflation factor of 3 (as suggested by Zuur et al., 2009), we considered densitometry, organic layer depth, stand age, live shrub biomass, woody debris, tree density, snag density, summer insolation, percent herbaceous cover, percent moss cover, percent lichen cover, percent other cover, soil $\mathrm{C}, \mathrm{BD}$, and root $\mathrm{C}$, as explanatory variables for the thaw depth model. For the soil $\mathrm{C}$ model the environmental variables considered were slope, summer insolation, snag biomass, live tree biomass, live shrub biomass, woody debris, tree density, percent herbaceous cover, percent moss cover, percent lichen cover, percent other cover, thaw depth, organic layer depth, root carbon, and moisture. The best model for each analysis was selected using backwards stepwise reduction of variables to obtain the lowest Akaike information criterion (AIC), and the residuals of all final models were checked for normality and homogeneity of variance (Burnham and Anderson, 2002).

All reported errors are the standard error of the mean. All statistical analyses were conducted using the statistical program R (R Core Development Team, 2012).

\section{Results}

\subsection{Distribution of carbon pools}

The majority of $\mathrm{C}$ in the watershed to $1 \mathrm{~m}$ depth was stored belowground ( $92 \% ; 10.9 \pm 0.8 \mathrm{~kg} \mathrm{C} \mathrm{m}^{-2}$ in top $1 \mathrm{~m}$; Fig. 2), with $19 \%$ in the top $10 \mathrm{~cm}$ of soil and $40 \%$ in the top $30 \mathrm{~cm}$. The top $10 \mathrm{~cm}$ of soil alone contained $58 \%$ more $\mathrm{C}$ than the total aboveground $\mathrm{C}$ stocks.

\subsection{Stand density, stand age, and aboveground biomass}

Stand density in the watershed ranged from 0.01 to 0.43 trees $\mathrm{m}^{-2}$ at the forested sites (mean density was $0.07 \pm 0.02$ trees $\mathrm{m}^{-2}$; Table 2). Mean stand age was 150 $( \pm 17)$ years (Table 1$)$, but there was a large range in tree ages among sites (23-221 years) and within sites (average range: 78 years; maximum range: 238 years; minimum range: 7 years; Table $S 1$ in the Supplement).

Total $\mathrm{C}$ in AGB averaged $959 \pm 150 \mathrm{~g} \mathrm{C} \mathrm{m}^{-2}$ across sites in the watershed, with $53 \%$ in larch biomass $\left(460 \pm 77 \mathrm{~g} \mathrm{C} \mathrm{m}^{-2}\right), \quad 30 \%$ in understory biomass $\left(254 \pm 28 \mathrm{~g} \mathrm{C} \mathrm{m}^{-2}\right), 11 \%$ in woody debris $\left(94 \pm 16.5 \mathrm{~g} \mathrm{C} \mathrm{m}^{-2}\right)$, and $6 \%$ in standing dead tree mass $\left(55 \pm 19 \mathrm{~g} \mathrm{C} \mathrm{m}^{-2}\right)$ (Fig. 2; Table 3). Among sites across the watershed, aboveground $\mathrm{C}$ varied up to $95 \%$. Together, all $\mathrm{C}$ in $\mathrm{AGB}$ contributed $8 \%$ to the total amount of $\mathrm{C}$ stored above- and belowground (to $1 \mathrm{~m}$ ) across the watershed. Mean stand age was positively related to mean stand AGB $\left(R^{2}=0.21, p<0.001\right)$ and negatively related to mean stand thaw depth $\left(R^{2}=0.58, p<0.001\right)$.

Aboveground larch biomass was also highly variable across the watershed, with some sites as low as 0 or $1.7 \mathrm{~g} \mathrm{C} \mathrm{m}^{-2}$ and others as high as 1340 and $1362 \mathrm{~g} \mathrm{C} \mathrm{m}^{-2}$. Of 
Table 2. Leaf area index (LAI), tree and snag density, and percent cover of the 20 plots in the Y4 watershed. Values in parentheses are standard error of the mean. "Other cover" includes woody debris and bare ground.

\begin{tabular}{|c|c|c|c|c|c|c|c|c|c|c|}
\hline $\begin{array}{l}\text { Site } \\
\text { number }\end{array}$ & $\begin{array}{r}\text { LAI } \\
\text { (hemispherical } \\
\text { photography) }\end{array}$ & $\begin{array}{r}\text { LAI } \\
(\text { LAI-2000) }\end{array}$ & $\begin{array}{r}\text { Larch } \\
\text { density } \\
\left(\text { trees } \mathrm{m}^{-2} \text { ) }\right.\end{array}$ & $\begin{array}{r}\text { Snag } \\
\text { density } \\
\left(\text { snags } \mathrm{m}^{-2}\right)\end{array}$ & $\begin{array}{r}\text { Canopy } \\
\text { cover } \\
(\%)\end{array}$ & $\begin{array}{r}\text { Understory } \\
\text { shrub cover } \\
(\%)\end{array}$ & $\begin{array}{r}\text { Herbaceous } \\
\text { cover } \\
(\%)\end{array}$ & $\begin{array}{r}\text { Moss } \\
\text { cover } \\
(\%)\end{array}$ & $\begin{array}{r}\text { Lichen } \\
\text { cover } \\
(\%)\end{array}$ & $\begin{array}{r}\text { Other } \\
\text { cover } \\
(\%)\end{array}$ \\
\hline 1 & $0.03(0.00)$ & 0.13 & $0.09(0.05)$ & 0.00 & $22.4(3.2)$ & $45.2(2.7)$ & $3.5(1.7)$ & $22.0(3.4)$ & $15.6(4.9)$ & $12.4(3.4)$ \\
\hline 2 & $0.22(0.02)$ & 0.13 & $0.04(0.00)$ & 0.00 & $16.0(4.0)$ & $49.4(5.4)$ & $4.8(2.4)$ & $25.0(4.4)$ & $6.9(2.9)$ & $13.8(6.0)$ \\
\hline 3 & $0.53(0.03)$ & 0.68 & $0.08(0.03)$ & 0.00 & $43.2(7.4)$ & $60.3(9.0)$ & $0.7(0.3)$ & $31.3(9.4)$ & $3.4(2.6)$ & $4.3(0.6)$ \\
\hline 4 & $0.02(0.01)$ & 0.00 & $0.08(0.07)$ & 0.00 & $2.6(2.6)$ & $72.3(7.9)$ & $2.5(1.6)$ & $7.4(2.4)$ & $3.4(2.1)$ & $14.3(5.7)$ \\
\hline 5 & $0.37(0.05)$ & 1.35 & $0.08(0.02)$ & $0.03(0.01)$ & $32.3(7.6)$ & $51.5(4.9)$ & $4.2(1.4)$ & $14.4(2.9)$ & $16.9(4.1)$ & $13.1(2.4)$ \\
\hline 6 & $0.38(0.03)$ & 0.47 & $0.06(0.01)$ & $0.03(0.01)$ & $26.0(4.6)$ & $57.9(7.2)$ & $8.4(5.9)$ & $17.4(5.2)$ & $3.6(1.3)$ & $12.1(3.8)$ \\
\hline 7 & $0.15(0.08)$ & 0.00 & $0.05(0.02)$ & 0.00 & $17.6(8.4)$ & $34.8(3.5)$ & $3.4(0.8)$ & $34.0(7.1)$ & $22.8(6.4)$ & $4.8(1.9)$ \\
\hline 8 & $0.06(0.04)$ & 0.29 & $0.02(0.00)$ & 0.00 & $7.0(2.1)$ & $34.8(4.5)$ & $3.8(1.8)$ & $32.5(7.9)$ & $24.8(9.5)$ & $4.0(2.3)$ \\
\hline 9 & $0.07(0.02)$ & 0.00 & $0.01(0.00)$ & 0.00 & $9.4(1.6)$ & $44.2(5.5)$ & 0.0 & $33.5(5.0)$ & $16.7(7.6)$ & $5.6(1.6)$ \\
\hline 10 & $0.30(0.09)$ & 1.41 & $0.08(0.04)$ & $0.04(0.02)$ & $24.3(6.2)$ & $49.2(10.6)$ & $8.6(2.9)$ & $29.8(8.8)$ & $5.3(1.4)$ & $7.1(2.5)$ \\
\hline 11 & $0.05(0.03)$ & 0.22 & $0.02(0.01)$ & 0.00 & $4.7(1.5)$ & $33.6(6.9)$ & $5.8(3.0)$ & $15.3(4.5)$ & $30.6(8.0)$ & $15.0(5.9)$ \\
\hline 12 & $0.01(0.00)$ & 0.00 & $0.02(0.01)$ & 0.00 & $0.0(0.0)$ & $47.1(7.4)$ & $7.5(4.0)$ & $20.2(3.7)$ & $19.0(5.3)$ & $6.9(3.2)$ \\
\hline 13 & $0.23(0.07)$ & 0.82 & $0.07(0.01)$ & $0.02(0.01)$ & $18.9(3.0)$ & $47.4(8.1)$ & $4.2(2.6)$ & $25.6(8.2)$ & $13.6(6.2)$ & $9.1(0.8)$ \\
\hline 14 & $0.00(0.00)$ & 0.00 & $0.03(0.02)$ & 0.00 & $0.8(0.8)$ & $47.2(12.0)$ & $5.8(3.7)$ & $11.3(3.8)$ & 33.5 (13.9) & $2.3(1.1)$ \\
\hline 15 & $0.03(0.01)$ & 0.00 & $0.02(0.01)$ & 0.00 & $3.8(1.0)$ & $41.3(3.9)$ & $3.8(1.7)$ & $22.4(4.5)$ & $21.9(4.6)$ & $10.4(5.5)$ \\
\hline 16 & $0.31(0.13)$ & 0.88 & $0.05(0.01)$ & 0.00 & $18.5(7.7)$ & $35.6(7.6)$ & $2.2(0.6)$ & $32.2(11.6)$ & $25.9(9.0)$ & $4.1(1.5)$ \\
\hline 17 & - & - & 0.0 & 0.00 & $13.9(13.9)$ & $65.8(15.1)$ & $11.1(4.4)$ & $0.1(0.1)$ & $0.1(0.1)$ & $23.4(11.5)$ \\
\hline 18 & - & - & $0.01(0.01)$ & 0.00 & 5.2 & $51.9(6.5)$ & $12.5(4.1)$ & $32.0(5.0)$ & $0.2(0.2)$ & $3.3(1.9)$ \\
\hline 19 & - & 2.03 & $0.43(0.28)$ & 0.00 & $16.2(2.2)$ & - & - & - & - & - \\
\hline 20 & - & - & $0.06(0.03)$ & $0.04(0.02)$ & $6.1(1.3)$ & - & - & - & - & - \\
\hline
\end{tabular}

Table 3. Aboveground biomass $\left(\mathrm{g} \mathrm{C} \mathrm{m}^{-2}\right)$ at each site in the $\mathrm{Y} 4$ watershed. Total aboveground biomass is the sum of the larch, understory vascular, standing dead tree, and woody debris biomass. Understory vascular biomass does not include lichen and moss. Values in parentheses are standard error of the mean.

\begin{tabular}{lrrrrrrrr}
\hline $\begin{array}{l}\text { Site } \\
\text { number }\end{array}$ & Larch & $\begin{array}{r}\text { Understory } \\
\text { vascular }\end{array}$ & Shrub & $\begin{array}{r}\text { Standing } \\
\text { dead tree }\end{array}$ & $\begin{array}{r}\text { Woody } \\
\text { debris }\end{array}$ & $\begin{array}{r}\text { Total } \\
\text { live }\end{array}$ & $\begin{array}{r}\text { Total } \\
\text { dead }\end{array}$ & $\begin{array}{r}\text { Total } \\
\text { aboveground }\end{array}$ \\
\hline 1 & $392(313)$ & $112(41)$ & $52(52)$ & $0(0)$ & $322(87)$ & $504(304)$ & $322(87)$ & $826(389)$ \\
2 & $603(244)$ & $140(50)$ & $75(40)$ & $0(0)$ & $76(7)$ & $744(213)$ & $76(7)$ & $820(217)$ \\
3 & $743(125)$ & $320(106)$ & $209(146)$ & $0(0)$ & $86(15)$ & $1063(230)$ & $86(15)$ & $1149(235)$ \\
4 & $67(66)$ & $611(166)$ & $529(176)$ & $0(0)$ & $59(17)$ & $679(153)$ & $59(17)$ & $737(167)$ \\
5 & $1362(516)$ & $193(27)$ & $96(32)$ & $219(96)$ & $122(28)$ & $1555(490)$ & $341(105)$ & $1896(579)$ \\
6 & $1340(635)$ & $257(81)$ & $146(69)$ & $386(236)$ & $131(50)$ & $1597(560)$ & $517(218)$ & $2114(361)$ \\
7 & $263(65)$ & $271(86)$ & $209(73)$ & $0(0)$ & $24(8)$ & $533(45)$ & $24(8)$ & $557(52)$ \\
8 & $471(303)$ & $170(115)$ & $124(108)$ & $27(27)$ & $10(3)$ & $641(294)$ & $37(29)$ & $678(319)$ \\
9 & $122(68)$ & $176(93)$ & $64(35)$ & $0(0)$ & $37(11)$ & $298(60)$ & $37(11)$ & $335(65)$ \\
10 & $697(405)$ & $183(64)$ & $51(51)$ & $262(140)$ & $106(16)$ & $880(400)$ & $368(153)$ & $1248(501)$ \\
11 & $227(201)$ & $185(87)$ & $95(95)$ & $0(0)$ & $62(17)$ & $413(285)$ & $62(17)$ & $475(278)$ \\
12 & $6(6)$ & $116(39)$ & $22(13)$ & $0(0)$ & $18(4)$ & $122(45)$ & $18(4)$ & $140(45)$ \\
13 & $698(124)$ & $139(25)$ & $32(18)$ & $93(69)$ & $306(189)$ & $837(126)$ & $399(146)$ & $1236(217)$ \\
14 & $5(4)$ & $253(184)$ & $169(152)$ & $0(0)$ & $16(2)$ & $259(183)$ & $16(2)$ & $275(181)$ \\
15 & $142(85)$ & $180(41)$ & $82(48)$ & $0(0)$ & $71(63)$ & $322(59)$ & $71(63)$ & $393(6)$ \\
16 & $984(491)$ & $470(256)$ & $417(261)$ & $0(0)$ & $56(21)$ & $1454(628)$ & $56(21)$ & $1510(633)$ \\
17 & $0(0)$ & $2657(2575)$ & $2621(2588)$ & $0(0)$ & $118(72)$ & $2657(2575)$ & $118(72)$ & $2775(2642)$ \\
18 & $2(2)$ & $263(46)$ & $245(42)$ & $0(0)$ & $16(5)$ & $265(47)$ & $16(5)$ & $281(50)$ \\
19 & $35(21)$ & $465(172)$ & $382(177)$ & $0(0)$ & $116(45)$ & $500(159)$ & $116(45)$ & $615(196)$ \\
20 & $585(217)$ & $321(163)$ & $156(105)$ & $47(26)$ & $158(140)$ & $906(173)$ & $205(118)$ & $1111(244)$ \\
\hline & & & & & & &
\end{tabular}


Table 4. Soil carbon in the $\mathrm{Y} 4$ watershed. Thawed soil cores were sampled from six locations per site. Permafrost cores were sampled to $1 \mathrm{~m}$ at seven sites (three per site). Root $\mathrm{C}$ and soil $\mathrm{C}$ values were normalized to $10 \mathrm{~cm}$. The combined soil $\mathrm{C}$ value is the amount of $\mathrm{C}$ in the top $10 \mathrm{~cm}$ of soil, regardless of soil type (mineral/organic). Carbon pools from the permafrost cores include active-layer soil (0-30 or 0-100 $\mathrm{cm}$ from top of ground surface). Values in parentheses are standard error of the mean.

\begin{tabular}{|c|c|c|c|c|c|c|c|}
\hline \multirow[t]{3}{*}{ Site number } & \multicolumn{5}{|c|}{ Thawed soil cores } & \multicolumn{2}{|c|}{ Permafrost cores } \\
\hline & \multicolumn{2}{|c|}{$\operatorname{Root} \mathrm{C}\left(\mathrm{g} \mathrm{C} \mathrm{m}^{-2}\right)$} & \multicolumn{3}{|c|}{ Soil C $\left(\mathrm{kg} \mathrm{C} \mathrm{m}^{-2}\right)$} & \multirow{2}{*}{$\begin{array}{l}\mathrm{C} \text { in top } 30 \mathrm{~cm} \\
\left(\mathrm{~kg} \mathrm{C} \mathrm{m}^{-3}\right)\end{array}$} & \multirow{2}{*}{$\begin{array}{r}\mathrm{C} \text { in top } 100 \mathrm{~cm} \\
\quad\left(\mathrm{~kg} \mathrm{C} \mathrm{m}^{-3}\right)\end{array}$} \\
\hline & Organic & Mineral & Organic & Mineral & Combined & & \\
\hline 1 & $137(27)$ & 0 & $2.60(0.27)$ & $2.03(0.21)$ & $2.34(0.22)$ & $4.69(0.06)$ & $9.36(0.09)$ \\
\hline 2 & $97(60)$ & 0 & $1.35(0.11)$ & $1.46(0.32)$ & $1.32(0.12)$ & $3.67(0.34)$ & $10.16(0.60)$ \\
\hline 3 & $108(42)$ & 0 & $1.86(0.32)$ & $1.43(0.19)$ & $1.83(0.29)$ & & \\
\hline 4 & $169(183)$ & 0 & $2.06(0.47)$ & $2.06(0.22)$ & $2.49(0.48)$ & & \\
\hline 5 & $453(108)$ & 0 & $4.47(1.74)$ & $1.57(0.05)$ & $3.42(0.76)$ & & \\
\hline 6 & $230(169)$ & 0 & $3.86(1.03)$ & $2.22(0.43)$ & $3.71(0.93)$ & & \\
\hline 7 & $44(22)$ & 0 & $1.13(0.22)$ & $2.31(0.41)$ & $1.14(0.22)$ & $4.29(0.32)$ & $10.48(0.67)$ \\
\hline 8 & $69(25)$ & 0 & $1.25(0.12)$ & $2.79(0.67)$ & $1.38(0.19)$ & & \\
\hline 9 & 177 (17) & $45(31)$ & $2.51(0.26)$ & $1.54(0.33)$ & $2.41(0.40)$ & $4.85(0.36)$ & $8.63(0.71)$ \\
\hline 10 & $278(35)$ & 0 & $2.12(0.45)$ & $1.36(0.12)$ & $2.10(0.46)$ & $4.82(0.44)$ & $9.39(0.06)$ \\
\hline 11 & $520(346)$ & $6(4)$ & $1.63(0.42)$ & $2.02(0.16)$ & $1.66(0.30)$ & & \\
\hline 12 & $271(87)$ & 0 & $1.39(0.04)$ & $3.26(0.83)$ & $1.51(0.05)$ & & \\
\hline 13 & $267(30)$ & 0 & $1.65(0.28)$ & $1.96(0.29)$ & $1.66(0.29)$ & & \\
\hline 14 & $252(74)$ & $6(4)$ & $3.12(0.47)$ & $1.31(0.26)$ & $2.74(0.15)$ & & \\
\hline 15 & $103(8)$ & 0 & $2.04(0.58)$ & $2.15(0.53)$ & $1.84(0.38)$ & & \\
\hline 16 & 189 (184) & $20(11)$ & $1.70(0.57)$ & $2.08(0.49)$ & $1.66(0.33)$ & $5.32(1.19)$ & $11.90(3.83)$ \\
\hline 17 & 0 & $97(35)$ & - & $2.37(0.21)$ & $2.76(0.78)$ & & \\
\hline 18 & $95(36)$ & 0 & $2.19(0.40)$ & $2.66(2.21)$ & $1.49(0.55)$ & & \\
\hline 19 & $205(91)$ & $203(152)$ & $3.51(0.47)$ & $2.74(1.23)$ & $2.85(0.72)$ & & \\
\hline 20 & 0 & 0 & $2.44(0.70)$ & $1.41(0.26)$ & $1.85(0.43)$ & $5.70(0.55)$ & $11.91(0.90)$ \\
\hline
\end{tabular}

the three techniques used for estimating canopy cover, LAI values from hemispherical photography (Table 2) showed the highest correlation with larch biomass $\left(R^{2}=0.69\right.$, $p<0.001$ ), but larch biomass was also significantly associated with canopy density $\left(R^{2}=0.5, p<0.001\right)$. There was no relationship between larch biomass and understory biomass $(p=0.4)$; however, the percent cover of tall shrubs was negatively related to both moss $\left(R^{2}=0.2, p<0.001\right)$ and lichen cover $\left(R^{2}=0.2, p<0.001\right)$.

\subsection{Surface soils}

Average $\mathrm{C}$ content of the organic horizon was 37.6 $( \pm 0.8) \% \mathrm{C}$, whereas $\mathrm{C}$ content of the thawed mineral horizon $(0-10 \mathrm{~cm})$ was $4.6( \pm 0.48) \%$ C. There was $2.24( \pm 1.22) \mathrm{kg} \mathrm{C} \mathrm{m}^{-2}$ stored in the organic layer (average organic layer depth $=11.2 \pm 0.2 \mathrm{~cm}$ ) and 1.96 $( \pm 0.07) \mathrm{kg} \mathrm{C} \mathrm{m}^{-2}$ in the top $10 \mathrm{~cm}$ of the mineral layer (Table 4).

There was large variation in $\mathrm{BD}$, soil moisture (GWC), soil $\mathrm{C}$ content, and thaw depth among sites (Table 5). Carbon content and GWC were more variable in mineral soils than in organic $\left(\mathrm{CV}_{\text {mineral }}=0.55\right.$ for percent $\mathrm{C}$ and 0.48 for $\mathrm{GWC}$; $\mathrm{CV}_{\text {organic }}=0.15$ for percent $\mathrm{C}$ and 0.36 for GWC), while $\mathrm{BD}$ was more variable in organic soils $\left(\mathrm{CV}_{\text {organic }}=0.51\right.$;
$\mathrm{CV}_{\text {mineral }}=0.3$ ). While the $\mathrm{CV}$ of thaw depth was not particularly high (0.28), the difference between the sites with the highest and lowest thaw depth measured was still $65 \%$, underscoring the heterogeneity of soil properties across the watershed. Variation in thaw depth was primarily due to stand age (Fig. 3; Table S2).

Soil $\mathrm{C}$ density in the top $10 \mathrm{~cm}$ of the ground surface (i.e., $0-10 \mathrm{~cm}$ soil depth, which may have contained both organic and mineral soils) varied up to $93 \%$ across the watershed (range: $0.51-7.14 \mathrm{~kg} \mathrm{C} \mathrm{m}^{-2}$; Tables 4 and $\mathrm{S} 2$ ), but the $\mathrm{CV}$ was larger within sites (0.32) than it was between sites $(0.26)$, indicating that soil $\mathrm{C}$ is more variable at the meter scale than it is at the kilometer scale. The distribution of soil $\mathrm{C}$ density in the top $10 \mathrm{~cm}$ was best explained by soil moisture, percent moss, and percent lichen cover (Table S2); soil C density was positively related to soil moisture and negatively related to percent moss and lichen cover (Fig. 4).

Soil in the top $30 \mathrm{~cm}$ of the profile contained on average $4.8 \pm 0.3 \mathrm{~kg} \mathrm{C} \mathrm{m}^{-2}$, but soil $\mathrm{C}$ density in the top $30 \mathrm{~cm}$ varied by $56 \%$ across the watershed as a whole. The average $\mathrm{CV}$ within a site was 0.16 , whereas the $\mathrm{CV}$ among sites was 0.22 , indicating $C$ density at $30 \mathrm{~cm}$ is similar or more variable across the watershed than at the meter scale. The top $1 \mathrm{~m}$ of soil contained $10.9 \pm 0.8 \mathrm{~kg} \mathrm{C} \mathrm{m}^{-2}\left(13.8 \pm 3.0 \mathrm{~kg} \mathrm{C} \mathrm{m}^{-2}\right.$ 
Table 5. Properties of thawed soil in the Y4 watershed. The mineral layer was collected to approximately $10 \mathrm{~cm}$ below the organic layer (see Methods section). No relationship existed between sample date and thaw depth or sample date and water content. Values in parentheses are standard error.

\begin{tabular}{|c|c|c|c|c|c|c|c|c|}
\hline \multirow[t]{2}{*}{$\begin{array}{l}\text { Site } \\
\text { number }\end{array}$} & \multirow{2}{*}{$\begin{array}{r}\text { Thaw } \\
\text { depth } \\
(\mathrm{cm})\end{array}$} & \multirow{2}{*}{$\begin{array}{r}\text { Organic } \\
\text { layer } \\
\text { depth }(\mathrm{cm})\end{array}$} & \multicolumn{2}{|c|}{$\begin{array}{l}\text { Bulk density } \\
\left(\mathrm{g} \mathrm{cm}^{-3}\right)\end{array}$} & \multicolumn{2}{|c|}{$\begin{array}{c}\text { Gravimetric water } \\
\text { content }(\%)\end{array}$} & \multicolumn{2}{|c|}{$\begin{array}{c}\text { Carbon content } \\
(\%)\end{array}$} \\
\hline & & & Organic & Mineral & Organic & Mineral & Organic & Mineral \\
\hline 1 & $23(1)$ & $13(1)$ & $0.078(0.021)$ & $0.52(0.16)$ & $198.9(34.4)$ & $64.7(17.4)$ & $37.6(3.5)$ & $6.9(2.5)$ \\
\hline 2 & $22(1)$ & $11(1)$ & $0.040(0.011)$ & $0.64(0.05)$ & $203.8(28.0)$ & $33.9(5.8)$ & $38.3(4.1)$ & $2.4(0.5)$ \\
\hline 3 & $24(1)$ & $14(1)$ & $0.062(0.011)$ & $0.70(0.11)$ & $103.3(16.2)$ & 29.1 (4.4) & $30.4(2.2)$ & $2.3(0.6)$ \\
\hline 4 & $41(2)$ & $10(1)$ & $0.148(0.063)$ & $0.54(0.14)$ & $107.3(28.9)$ & $61.0(15.6)$ & $26.6(4.0)$ & $8.7(3.0)$ \\
\hline 5 & $23(1)$ & $8(1)$ & $0.120(0.032)$ & $1.02(0.08)$ & $220.2(23.1)$ & $25.6(2.1)$ & $39.2(3.2)$ & $1.6(0.3)$ \\
\hline 6 & $21(2)$ & $9(1)$ & $0.113(0.039)$ & $0.63(0.05)$ & $182.0(19.8)$ & $34.2(6.1)$ & $39.0(3.0)$ & $3.8(1.0)$ \\
\hline 7 & $21(1)$ & $12(1)$ & $0.026(0.005)$ & $0.76(0.18)$ & 348.5 (48.4) & $43.6(10.2)$ & $44.4(2.0)$ & $3.9(1.2)$ \\
\hline 8 & $16(1)$ & $11(1)$ & $0.027(0.002)$ & $0.68(0.10)$ & $304.9(32.1)$ & $46.4(10.3)$ & $46.7(0.6)$ & $4.4(1.1)$ \\
\hline 9 & $26(2)$ & $13(1)$ & $0.082(0.010)$ & $0.64(0.12)$ & $171.3(29.5)$ & $46.5(11.2)$ & 30.9 (4.4) & $5.5(2.1)$ \\
\hline 10 & $23(1)$ & $11(1)$ & $0.048(0.007)$ & $0.89(0.05)$ & $272.6(15.2)$ & $26.5(1.7)$ & $43.6(1.9)$ & $1.6(0.2)$ \\
\hline 11 & $35(2)$ & $10(1)$ & $0.060(0.023)$ & $0.84(0.12)$ & $142.8(17.8)$ & $39.4(6.9)$ & $30.5(3.3)$ & $3.6(1.6)$ \\
\hline 12 & $29(2)$ & $10(1)$ & $0.053(0.020)$ & $0.67(0.10)$ & $247.7(17.5)$ & $58.3(10.7)$ & $43.5(1.8)$ & $5.0(1.0)$ \\
\hline 13 & $29(1)$ & $12(1)$ & $0.042(0.008)$ & $0.71(0.11)$ & $194.1(15.4)$ & $48.6(12.6)$ & $40.0(1.4)$ & $4.0(1.0)$ \\
\hline 14 & $42(2)$ & $8(1)$ & $0.103(0.016)$ & $0.82(0.10)$ & $165.8(14.7)$ & $31.0(7.2)$ & $32.4(3.8)$ & $3.0(1.6)$ \\
\hline 15 & $28(2)$ & $12(1)$ & $0.150(0.099)$ & $0.92(0.10)$ & 419.1 (105.4) & $39.9(10.6)$ & $38.3(3.5)$ & $2.6(0.9)$ \\
\hline 16 & $24(1)$ & $12(1)$ & $0.042(0.009)$ & $0.76(0.18)$ & 256.3 & $49.5(15.8)$ & $40.2(2.1)$ & $5.9(3.4)$ \\
\hline 17 & $45(2)$ & $9(2)$ & - & $0.46(0.11)$ & - & $50.9(7.6)$ & - & $8.7(2.8)$ \\
\hline 18 & $26(1)$ & $18(1)$ & $0.059(0.012)$ & $0.39(0.20)$ & 346.8 (45.4) & $123.2(31.2)$ & $39.9(3.3)$ & $8.7(2.6)$ \\
\hline 19 & $36(2)$ & $14(2)$ & $0.078(0.022)$ & $1.40(0.09)$ & $204.9(52.3)$ & $22.8(0.4)$ & $33.5(3.4)$ & $1.0(0.1)$ \\
\hline 20 & $29(1)$ & $9(1)$ & $0.118(0.001)$ & $0.65(0.31)$ & $252.9(76.6)$ & $76.1(28.4)$ & 29.9 (4.4) & $8.6(4.9)$ \\
\hline
\end{tabular}

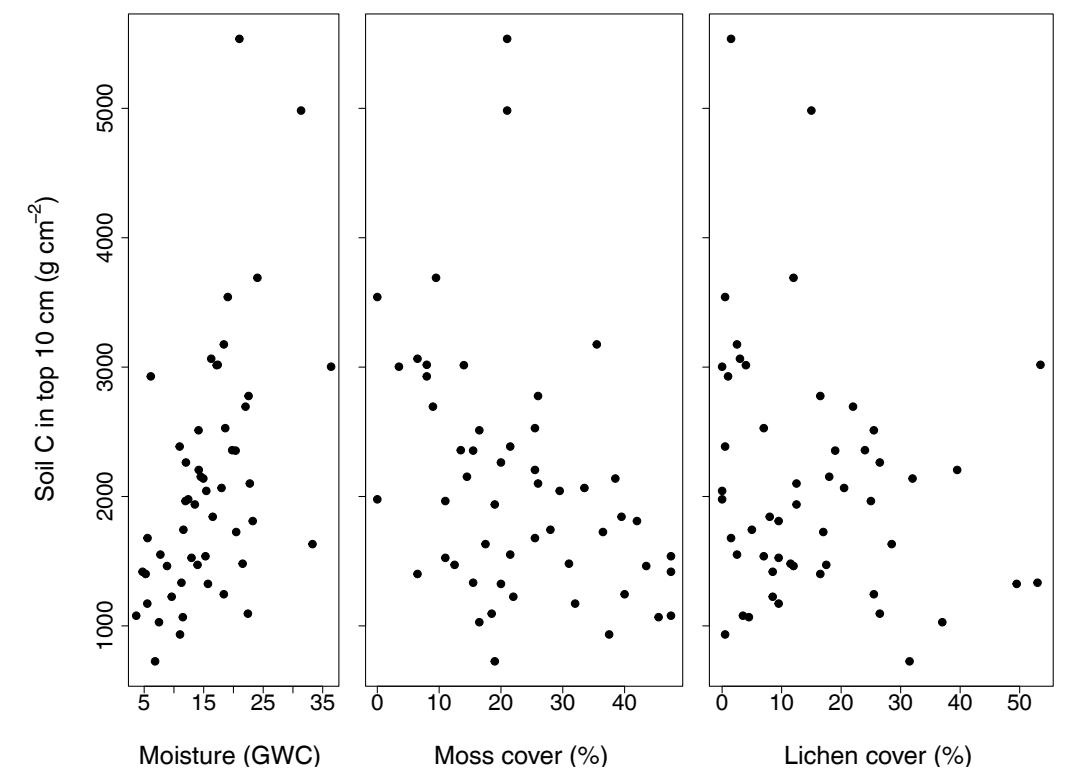

Figure 3. Relationship between SOC in the top $10 \mathrm{~cm}$ of soil and moisture, moss cover, and lichen cover. Each point represents the average SOC measured at each transect (three transects per site) and its corresponding moisture content or the average moss or lichen cover measured at that transect. 


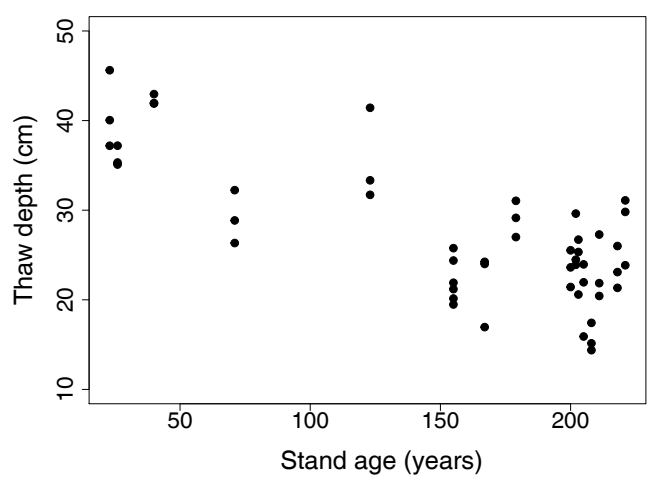

Figure 4. Relationship between thaw depth and stand age. Each point represents the average thaw depth measurement taken along a transect (three transects per site) and the stand age of the entire site. Thaw depths were measured in July/August of 2012 and 2013.

at alas site; Table S4). Soil $\mathrm{C}$ in the top $1 \mathrm{~m}$ varied by $63 \%$ across the watershed and by $44 \%$ among sites. The average $\mathrm{CV}$ within a site was 0.15 , whereas among sites the $\mathrm{CV}$ was 0.20 , indicating soil $\mathrm{C}$ to $1 \mathrm{~m}$ is similarly variable at the meter and kilometer scales. Ice content in the top $1 \mathrm{~m}$ was on average $68 \pm 2 \%$ by volume, with a range of between 51 and $80 \%$.

\subsection{Deep permafrost soils}

Deep permafrost soils (including surface active layer to $15 \mathrm{~m}$ ) contained $205 \mathrm{~kg} \mathrm{C} \mathrm{m}^{-2}$ (site 19; yedoma deposit, nonice wedge) and $331 \mathrm{~kg} \mathrm{C} \mathrm{m}^{-2}$ (site 18; alas). Carbon density at each $1 \mathrm{~m}$ interval ranged from 7.87 to $21.63 \mathrm{~kg} \mathrm{C} \mathrm{m}^{-3}$ in the yedoma deposit and from 6.9 to $14.5 \mathrm{~kg} \mathrm{C} \mathrm{m}^{-3}$ in the deeper portion of the alas (Fig. 5; Table S5). The top $2 \mathrm{~m}$ of the alas was characterized by particularly high $\mathrm{C}$ density $\left(\sim 30 \mathrm{~kg} \mathrm{~m}^{-3}\right)$.

Highlighting the variability of $\mathrm{C}$ in deep permafrost, the total soil $\mathrm{C}$ density in the two cores varied by $38 \%$. The alas site had higher GWC than the yedoma site in the first $2 \mathrm{~m}$ (GWC: $385 \pm 81$ and $41 \pm 8 \%$, respectively). Throughout the entire profile, GWC was $46 \pm 2 \%$ in the yedoma core and $100 \pm 23 \%$ in the alas core. Overall, BD was similar between the two cores, and most of the variation in BD occurred in the top $5 \mathrm{~m}$ (Fig. 5).

\section{Discussion}

\subsection{Aboveground biomass}

Aboveground $\mathrm{C}$ pools within the $\mathrm{Y} 4$ watershed represented only a small fraction ( $8 \%$ ) of total C pools, likely due to low tree density at most sites $\left(<0.09\right.$ trees $^{-2}$ at all but one site) and/or young stand ages at a few sites. Low-density, mature ( $>75$ years old) stands with no recent fire activity are common in this region (Berner et al., 2012); however, wildfires can produce stands of considerably higher density $\left(>3\right.$ trees $\mathrm{m}^{-2}$ ), which can substantially increase AGB and contribution to total $\mathrm{C}$ pools as stands mature (Alexander et al., 2012). Aboveground $C$ pools were similar to those reported by Alexander et al. (2012) for 17 nearby stands of similar age and density, but $\mathrm{C}$ in larch AGB was lower $(\sim 23 \%)$ than a landscape-level estimate $\left(\sim 600 \mathrm{~g} \mathrm{C} \mathrm{m}^{-2}\right)$ across the Kolyma River basin (Berner et al., 2012). Our estimate for $\mathrm{C}$ stored in larch AGB was also 4 times lower than that of a mature (155-year-old), mid-density $\left(0.19\right.$ trees $\left.\mathrm{m}^{-2}\right)$ stand near Chersky and 2 times lower than a mature, low-density $\left(0.08\right.$ trees $\left.\mathrm{m}^{-2}\right)$ stand near Oymyakon, south of Chersky (Kajimoto et al., 2006). In addition, our larch AGB estimates fell within the low range of larch stands across other high-latitude $\left(>64^{\circ} \mathrm{N}\right)$ regions and were generally 3-10 times lower than other stands (Kajimoto et al., 2010). Our considerably lower estimates reflect both the sparse, opengrown structure of our stands (Osawa and Kajimoto, 2010) and the poor soil environment (e.g., shallow rooting zone, low soil temperature, low $\mathrm{N}$ availability) found in stands near the latitudinal and altitudinal tree line (Kajimoto et al., 2010). Despite the small contribution of AGB to total C pools across our stands, aboveground vegetation composition and structure were important factors related to soil C pools and permafrost thaw (see below). In addition, characteristics of aboveground vegetation are major determinants of landatmosphere C fluxes (Bradshaw and Warkentin, 2015) and thus remain essential components of $\mathrm{C}$ dynamics even when pools are relatively low.

\subsection{Variability of soil C pools}

Soil C density is controlled by numerous biogeophysical factors such as climate, local geomorphology, soil parent material, time since last disturbance, and vegetation type, all of which lead to high variability in soil $\mathrm{C}$ pools at the regional and local scale. Our soil C pool estimates for a Siberian larch forest watershed fall within the range of published assessments that characterize this area (Alexander et al., 2012; Broderick et al., 2015) but are at the low end of other studies (Alexeyev and Birdsey, 1998; Hugelius et al., 2014; Matsuura et al., 2005; Palmtag et al., 2015; Stolbovoi, 2006). For example, our mean estimate of $4.8 \pm 1 \mathrm{~kg} \mathrm{C} \mathrm{m}^{-2}$ in the top $30 \mathrm{~cm}$ of soil is less than half of a published assessment of C stored in soils across Russian larch forests $\left(10.2 \mathrm{~kg} \mathrm{C} \mathrm{m}^{-2}\right.$; Stolbovoi, 2006) and less than one-third of the mean estimate for Turbel soils across the permafrost region $\left(14.7 \mathrm{~kg} \mathrm{C} \mathrm{m}^{-2}\right.$; Hugelius et al., 2014); however, variation in the permafrost region Turbel soil $\mathrm{C}$ pool is high $(\mathrm{CV}=0.85$; Hugelius et al., 2014), and our mean estimate falls within 1 standard deviation of this regional mean.

Within larch forests, there is substantial variation in soil C pools at regional scales, driven by variation in soil parent material and climate. For example, larch forests in Northeastern Siberia store significantly more $\mathrm{C}\left(16 \mathrm{~kg} \mathrm{C} \mathrm{m}^{-2}\right)$ in the ac- 

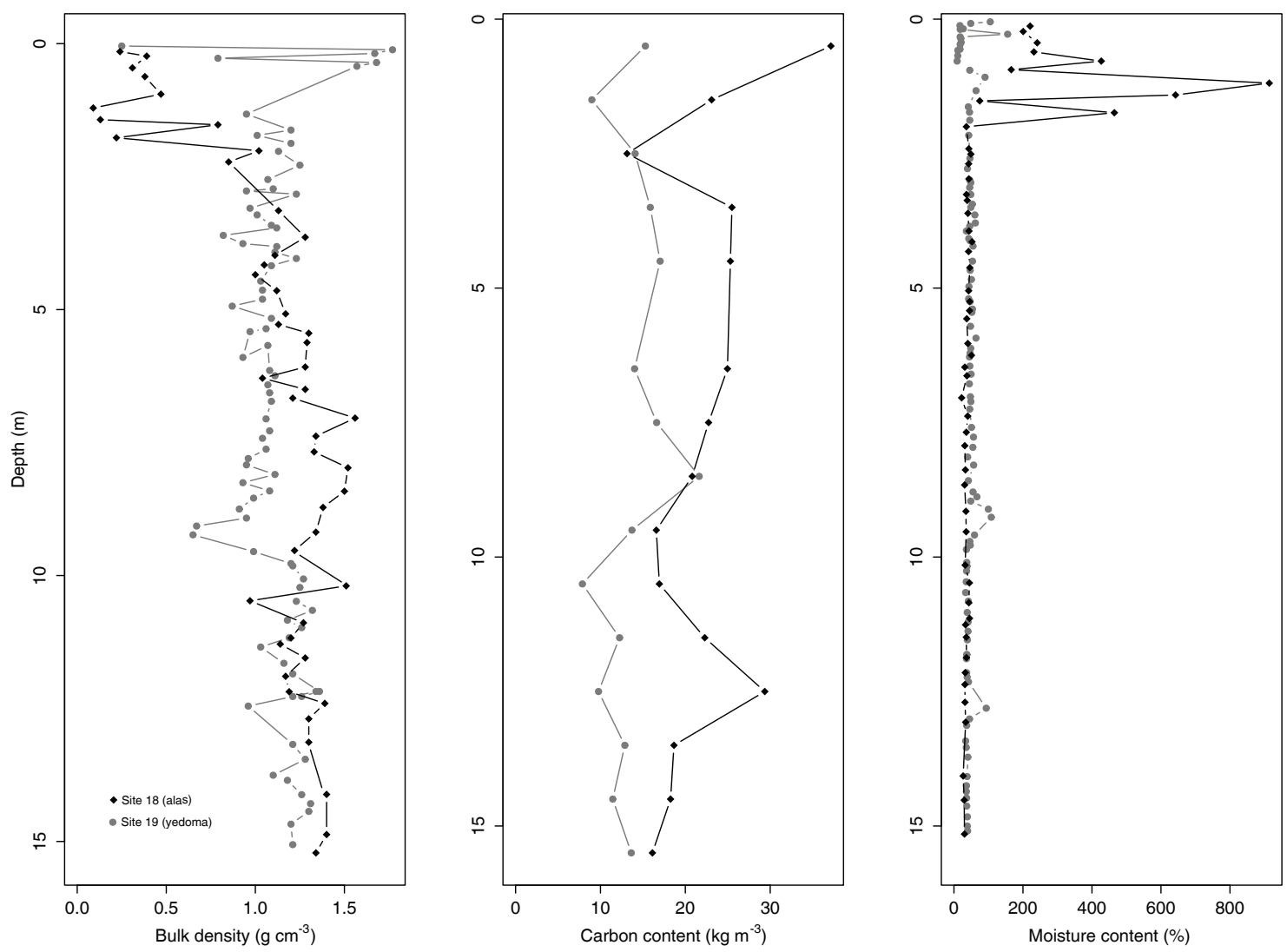

Figure 5. Bulk density, carbon density, and ice content of the two deep (15 m) permafrost soil cores.

tive layer and have more variable soil $\mathrm{C}$ pool estimates than larch forests in central Siberia $\left(6.3 \mathrm{~kg} \mathrm{C} \mathrm{m}^{-2}\right)$ (Matsuura and Hirobe, 2010). There is also considerable variation in soil $\mathrm{C}$ pools within larch forests at smaller spatial scales. Indeed, the active layer in larch forests located within $50 \mathrm{~km}$ from our study site contained twice as much $\mathrm{C}$ as found in our study $\left(4.8 \pm 0.3 \mathrm{~kg} \mathrm{C} \mathrm{m}^{-2}\right.$ to $\left.30 \mathrm{~cm}\right)$; there was $8.3 \mathrm{~kg} \mathrm{C} \mathrm{m}^{-2}$ in the active layer $(38 \mathrm{~cm})$ of a larch forest $44 \mathrm{~km}$ from the $\mathrm{Y} 4$ watershed (Matsuura et al., 2005) and $9.5 \pm 2.9$ (SD) $\mathrm{kg} \mathrm{C} \mathrm{m}^{-2}$ in the top $30 \mathrm{~cm}$ of soils from a forest $3 \mathrm{~km}$ away (Palmtag et al., 2015). This variation in soil $\mathrm{C}$ pools points to the extreme variability in soil $\mathrm{C}$ throughout the landscape, even at the kilometer scale. It also highlights the importance of sampling replication at small scales; with 21 total soil cores at seven sites, our CV (0.13) was less than half of other studies with lower site-level replication (Palmtag et al., 2015).

As the climate warms, $\mathrm{C}$ in surface permafrost is becoming increasingly vulnerable to thawing and subsequent decomposition and loss to the atmosphere. As such, estimating variation in $\mathrm{C}$ pool size is critical for understanding permafrostclimate feedbacks. The $\mathrm{C}$ stored in the top $1 \mathrm{~m}$ of $\mathrm{Y} 4$ soils $\left(10.9 \pm 0.8 \mathrm{~kg} \mathrm{C} \mathrm{m}^{-2}\right)$ was similar to the average $1 \mathrm{~m} \mathrm{C}$ pool reported for the Yakutia region, which comprises a range of ecosystem types $\left(8.1 \mathrm{~kg} \mathrm{C} \mathrm{m}^{-2}\right.$; Alexeyev and Birdsey,
1998), but $37 \%$ lower than the $1 \mathrm{~m}$ soil $\mathrm{C}$ pool reported in a forest only $3 \mathrm{~km}$ away $\left(17.3 \pm 5.7 \mathrm{~kg} \mathrm{C} \mathrm{m}^{-2}\right.$; Palmtag et al., 2015). However, the percent difference between our estimate and the nearby study (37\%) was similar to the percent difference found between sites in the Y4 watershed (44\%; Table 4), suggesting that these differences among studies are likely due to natural variation in the landscape.

Carbon pool estimates from deep permafrost $(>3 \mathrm{~m}$ ) are limited across the Arctic (Hugelius et al., 2014; Schuur et al., 2015; Tarnocai et al., 2009), yet these data are critical for assessing variation in and controls on $\mathrm{C}$ density of yedoma, as these soils have particularly high $\mathrm{C}$ density at depth (Strauss et al., 2013; Zimov et al., 2006). The average carbon density of deep permafrost from yedoma deposits in the Y4 watershed $\left(13.5 \mathrm{~kg} \mathrm{C} \mathrm{m}^{-3}\right)$ was similar to values reported for yedoma in pan-Arctic summary studies (10 $+7 /-6 \mathrm{~kg} \mathrm{C} \mathrm{m}^{-3}$, Strauss et al., 2013; $13.0 \pm 0.75 \mathrm{~kg} \mathrm{C} \mathrm{m}^{-3}$ after correction for ice volume, Walter Anthony et al., 2014) and at taiga sites within $100 \mathrm{~km}$ of Chersky (12.3$15.4 \mathrm{~kg} \mathrm{C} \mathrm{m}^{-3}$ after correction for ice volume, Walter Anthony et al., 2014, and references therein; $14.3 \mathrm{~kg} \mathrm{C} \mathrm{m}^{-3}$, Shmelev et al., 2017). Carbon density was almost twice as high in the alas, which is consistent with findings indicating that alas and thermokarst soils store substantially more 
C ( 40-70\%; Walter Anthony et al., 2014; Strauss et al., 2013; Siewert et al., 2015) than undisturbed yedoma, a difference that is likely due to higher rates of recent (Holocene) $\mathrm{C}$ accumulation at the alas site (Walter Anthony et al., 2014). Yedoma is characterized by high landscape-level ice content due to the prevalence of large ice wedges, which can comprise 31 to $63 \%$ of ground volume (Ulrich et al., 2014). Accounting for these deep ice deposits, which were not sampled in this study, would reduce our landscape-level estimate of $\mathrm{C}$ content in the top $15 \mathrm{~m}$ of yedoma from 205 to $76-$ $141 \mathrm{~kg} \mathrm{C} \mathrm{m}^{-2}$, which is still an order of magnitude more $\mathrm{C}$ than is stored in the active layer and 2 orders of magnitude more $\mathrm{C}$ than is stored in biomass.

\subsection{Micro-scale variation in soil carbon and thaw depth}

In addition to the effects of parent material and climate on soil C storage, soil carbon pools are determined by the balance between biological inputs and losses due to microbial decomposition and lateral transport. These biological processes are, in turn, also heavily influenced by climate on regional and local scales. We found that soil samples with higher moisture content also had higher $\mathrm{C}$ density, which is likely due to both the effects of soil moisture on microbial activity and indirect effects of soil moisture on $\mathrm{C}$ inputs to soils through effects on plant productivity. In wetter soils, oxygen diffusion is limited, resulting in anaerobic conditions where microbial decomposition is slower, and $\mathrm{C}$ can accumulate at a higher rate than in more well-drained, well-aerated soils (Schädel et al., 2016). However, this positive association between moisture and $\mathrm{C}$ density may also be a result of increased $\mathrm{C}$ inputs and plant productivity associated with higher soil moisture (Berner et al., 2013) or the lateral movement of dissolved organic $\mathrm{C}$ into the wetter sites. It is likely that environmental controls on both $\mathrm{C}$ inputs and losses are driving the patterns of $\mathrm{C}$ accumulation across the watershed.

Plant species composition may also play an important role in soil C storage in boreal forests (Hollingsworth et al., 2008) through the quality and quantity of litter inputs and through vegetation effects on environmental controls such as soil moisture and temperature. Lichens and mosses are sometimes thought to encourage soil C storage through their promotion of low soil temperatures, higher moisture, and a relatively acidic environment (Bonan and Shugar, 1989). However, at our sites, increasing abundance of lichen and moss was associated with lower soil $\mathrm{C}$ storage, which may have been due to lower rates of C fixation (Turetsky et al., 2010), higher rates of decomposition of vascular plant litter in moss and lichen patches (Wardle et al., 2003), or impacts of vegetation functional types on soil moisture and soil temperatures. Because the interactions between soil processes and vegetation are bidirectional, the processes driving these observed patterns are unclear, and further experimental work is needed to identify the mechanisms.
Increasing thaw depth may result in increased $\mathrm{C}$ loss from boreal ecosystems; as more soil is thawed, more organic matter is available for decomposition. We found that thaw depth was negatively related to stand age; the deeper thaw depth observed at the younger sites could be a result of more recent burning events, which tend to increase thaw depth (O’Donnell et al., 2011; Yoshikawa et al., 2002).

\section{Conclusions}

We found that the overwhelming majority of $\mathrm{C}$ in the $\mathrm{Y} 4$ watershed was stored belowground but that the amount of $\mathrm{C}$ within any given pool was highly variable throughout the landscape; C storage in AGB varied up to $95 \%$ among sites, and there was $69 \%$ variation in the top $10 \mathrm{~cm}$ of soil, $36 \%$ in the top $30 \mathrm{~cm}$, and $28 \%$ in the top $1 \mathrm{~m}$. This variability among sites in our study was similar to the variability between our sites and others that were 3 to $50 \mathrm{~km}$ away (Matsuura et al., 2005; Palmtag et al., 2015), indicating a high level of natural variability at the meter and kilometer scales. Our results also indicate higher soil $\mathrm{C}$ variability in surface soils when compared to deeper soils, indicating that recent, ongoing processes significantly contribute to soil $\mathrm{C}$ variability. Specifically, our results show that soil moisture, aboveground biomass, and vegetation community structure are influential in explaining near-surface belowground $\mathrm{C}$ storage. These linkages between above- and belowground processes, such as the negative relationship between stand age and thaw depth, have important implications for soil C vulnerability as tree lines shift and biomass and stand structure are increasingly impacted by fire, climate, and direct human disturbances.

Data availability. All data are available in the Supplement and through the Arctic Data Center (https://doi.org/10.5065/D6NG4NP0, Heard et al., 2015).

\section{The Supplement related to this article is available online at https://doi.org/10.5194/bg-14-4279-2017-supplement.}

Author contributions. EW contributed to data collection and processing, analyzed data, created figures, and drafted the manuscript. $\mathrm{KH}$ collected, processed, and summarized data and contributed to writing. SN oversaw and contributed to data collection, processing, and analysis and writing. $\mathrm{AB}$ oversaw data collection, processing, and analysis. HA contributed to data collection and analysis and writing. LB contributed to data collection and processing and figure creation. ML contributed to data collection and processing. JS contributed to lab analyses. VS and AK collected and processed deep permafrost cores. NZ contributed to data collection. All authors reviewed the manuscript and provided critical feedback. 
Competing interests. The authors declare that they have no conflict of interest.

Acknowledgements. This project was supported by funding from the National Geographic Society (Susan M. Natali) and the National Science Foundation (NSF-1044610, NSF-1417745 NSF-1014180, NSF-1044417, NSF-1417700, NSF-1417908; Susan M. Natali, Susan M. Natali, John D. Schade, Andrew G. Bunn, Michael M. Loranty, Alexander Kholodov). We thank Sarah Shin and other Polaris Project 2013 participants for field and lab assistance, and the staff and scientists at the Northeast Science Station for logistical and field support.

Edited by: Jens-Arne Subke

Reviewed by: two anonymous referees

\section{References}

Alexander, H. D., Mack, M. C., Goetz, S., Loranty, M. M., Beck, P. S. A., Earl, K., Zimov, S., Davydov, S., and Thompson, C. C.: Carbon Accumulation Patterns During Post-Fire Succession in Cajander Larch (Larix cajanderi) Forests of Siberia, Ecosystems, 15, 1065-1082, https://doi.org/10.1007/s10021-012-95676, 2012

Alexeyev, V. A. and Birdsey, R. A.: Carbon Storage in Forests and Peatlands of Russia, Radnor, PA, 1998.

Beck, P. S. A., Juday, G. P., Alix, C., Barber, V. A., Winslow, S. E., Sousa, E. E., Heiser, P., Herriges, J. D., and Goetz, S. J.: Changes in forest productivity across Alaska consistent with biome shift, Ecol. Lett., 14, 373-379, https://doi.org/10.1111/j.14610248.2011.01598.x, 2011.

Beer, C.: Permafrost Sub-grid Heterogeneity of Soil Properties Key for 3-D Soil Processes and Future Climate Projections, Front. Earth Sci., 4, 1-7, https://doi.org/10.3389/feart.2016.00081, 2016.

Berg, E. E., Henry, J. D., Fastie, C. L., Volder, A. D. De, and Matsuoka, S. M.: Spruce beetle outbreaks on the Kenai Peninsula, Alaska, and Kluane National Park and Reserve, Yukon Territory?: Relationship to summer temperatures and regional differences in disturbance regimes, Forest Ecol. Manag., 227, 219232, https://doi.org/10.1016/j.foreco.2006.02.038, 2006.

Berner, L. T., Beck, P. S. A., Loranty, M. M., Alexander, H. D., Mack, M. C., and Goetz, S. J.: Cajander larch (Larix cajanderi) biomass distribution, fire regime and post-fire recovery in northeastern Siberia, Biogeosciences, 9, 3943-3959, https://doi.org/10.5194/bg-9-3943-2012, 2012

Berner, L. T., Beck, P. S. A., Bunn, A. G., and Goetz, S. J.: Plant response to climate change along the forest-tundra ecotone in northeastern Siberia, Glob. Change Biol., 19, 3449-3462, https://doi.org/10.1111/gcb.12304, 2013.

Berner, L. T., Alexander, H. D., Loranty, M. M., Ganzlin, P., Mack, M. C., Davydov, S. P., and Goetz, S. J.: Biomass allometry for alder, dwarf birch, and willow in boreal forest and tundra ecosystems of far northeastern Siberia and north-central Alaska, Forest Ecol. Manag., 337, 110-118, https://doi.org/10.1016/j.foreco.2014.10.027, 2015.
Bonan, G. B. and Shugar, H. H.: Environmental Factors and Ecological Processes in Boreal Forests, Annu. Rev. Ecol. Syst., 20, 1-28, 1989.

Bradshaw, C. and Warkentin, I. G.: Global estimates of boreal forest carbon stocks and flux, Global Planet. Change, 128, 24-30, https://doi.org/10.1016/j.gloplacha.2015.02.004, 2015.

Broderick, D. E., Frey, K. E., Rogan, J., Alexander, H. D., and Zimov, N. S.: Estimating upper soil horizon carbon stocks in a permafrost watershed of Northeast Siberia by integrating field measurements with Landsat-5 TM and WorldView-2 satellite data, GISci. Remote Sens., 52, https://doi.org/10.1080/15481603.2015.1010434, 2015.

Brown, J. K.: Handbook for Inventorying Downed Woody Material, Ogden, Utah, 1974

Burnham, K. P. and Anderson, D. R.: Model Selection and Multimodel Inference: A Practical Information-Theoretic Approach, 2nd Edn., Springer, New York, 2002.

Carvalhais, N., Forkel, M., Khomik, M., Bellarby, J., Jung, M., Migliavacca, M., Mu, M., Saatchi, S., Santoro, M., Thurner, M., Weber, U., Ahrens, B., Beer, C., Cescatti, A., Randerson, J. T., and Reichstein, M.: Global covariation of carbon turnover times with climate in terrestrial ecosystems, Nature, 514, 213-217, https://doi.org/10.1038/nature13731, 2014.

Chapin, F. S., McGuire, A. D., Randerson, J., Pielske, R., Baldocchi, D., Hobbie, S. E., Roulet, N., Eugster, W., Kasischke, E. S., Rastetter, E. B., Zimov, S. A., and Running, S. W.: Arctic and boreal ecosystmes of western North America as components of the climate system, Glob. Change Biol., 6, 211-223, 2000.

Chapin, F. S., Euskirchen, E. S., Tape, K. D., Thompson, C. D. C., Walker, D. A., McGuire, A. D., Rupp, T. S., Hinzman, L. D., Sturm, M., Serreze, M. C., McFadden, J. P., Key, J. R., Lloyd, A. H., Lynch, A. H., Beringer, J., Schimel, J. P., Chapman, W. L., Epstein, H. E., Jia, G., Ping, C.-L. L., Welker, J. M., McGuire, A. D., Rupp, T. S., Lynch, A. H., Schimel, J. P., Beringer, J., Chapman, W. L., Epstein, H. E., Euskirchen, E. S., Hinzman, L. D., Jia, G., Ping, C.-L. L., Tape, K. D., Thompson, C. D. C., Walker, D. A., and Welker, J. M.: Role of landsurface changes in arctic summer warming, Science, 310, 657660, https://doi.org/10.1126/science.1117368, 2005.

Chen, J. M., Rich, P. M., Gower, S. T., Norman, J. M., and Plummer, S.: Leaf area index of boreal forests: Theory, techniques, and measurements, J. Geophys. Res., 102, 429-443, https://doi.org/10.1029/97JD01107, 1997.

Chen, J. M., Menges, C. H., and Leblanc, S. G.: Global mapping of foliage clumping index using multi-angular satellite data, Remote Sens. Environ., 97, 447-457, https://doi.org/10.1016/j.rse.2005.05.003, 2005.

Christensen, J. H., Kumar, K. K., Aldrian, E., An, S.-I., Cavalcanti, I. F. A., Castro, M. de, Dong, W., Goswami, P., Hall, A., Kanyanga, J. K., Kitoh, A., Kossin, J., Lau, N.-C., Renwick, J., Stephenson, D. B., Xie, S.-P., and Zhou, T.: Climate Phenomena and their Relevance for Future Regional Climate Change, in: Climate Change 2013: The Physical Science Basis. Contribution of Working Group 1 to the fifth Assessment Report of the Intergovernmental Panel on Climate Change, edited by: Stocker, T., Qin, D., Plattner, G.-K., Tignor, M., Allen, S. K., Boschung, J., Nauels, A., Xia, Y., Bex, V., and Midgley, P. M., Cambridge University Press, Cambridge, UK and New York, NY, USA, 2013. 
Elmendorf, S. C., Henry, G. H. R., Hollister, R. D., Björk, R. G., Boulanger-Lapointe, N., Cooper, E. J., Cornelissen, J. H. C., Day, T. A., Dorrepaal, E., Elumeeva, T. G., Gill, M., Gould, W. A., Harte, J., Hik, D. S., Hofgaard, A., Johnson, D. R., Johnstone, J. F., Jónsdóttir, I. S., Jorgenson, J. C., Klanderud, K., Klein, J. A., Koh, S., Kudo, G., Lara, M., Lévesque, E., Magnússon, B., May, J. L., Mercado-Díaz, J. A., Michelsen, A., Molau, U., Myers-Smith, I. H., Oberbauer, S. F., Onipchenko, V. G., Rixen, C., Schmidt, N. M., Shaver, G. R., Spasojevic, M. J., Pórhallsdóttir, P. E., Tolvanen, A., Troxler, T., Tweedie, C. E., Villareal, S., Wahren, C.-H., Walker, X., Webber, P. J., Welker, J. M., and Wipf, S.: Plot-scale evidence of tundra vegetation change and links to recent summer warming, Nat. Clim. Chang., 2, 453-457, https://doi.org/10.1038/nclimate1465, 2012.

Euskirchen, E. S., Mcguire, A. D., Chapin, F. S., Yi, S., Thompson, C. C., and Thompson, C. C.: Changes in Vegetation in Northern Alaska under Scenarios of Climate Change, 2003-2100: Implications for Climate Feedbacks Changes in vegetation in northern Alaska under scenarios of climate change, 2003-2100: implications for climate feedbacks, Ecol. Appl., 19, 1022-1043, https://doi.org/10.1890/08-0806.1, 2009.

Fisher, J. P., Estop-Aragones, C., Thierry, A., Charman, D. J., Wolfe, S. A., Hartley, I. P., Murton, J. B., Williams, M., and Phoenix, G. K.: The influence of vegetation and soil characteristics on active-layer thickness of permafrost soils in boreal forest, Glob. Change Biol., 22, 3127-3140, https://doi.org/10.1111/gcb.13248, 2016.

Fu, P. and Rich, P.: A geometric solar radiation model with applications in agriculture and forestry, Comput. Electron. Agr., 37, 25-35, https://doi.org/10.1016/S0168-1699(02)00115-1, 2002.

Goetz, S. J., Mack, M. C., Gurney, K. R., Randerson, J. T., and Houghton, R. A.: Ecosystem responses to recent climate change and fire disturbance at northern high latitudes: observations and model results contrasting northern Eurasia and North America, Environ. Res. Lett., 2, 45031, https://doi.org/10.1088/17489326/2/4/045031, 2007.

Grosse, G., Robinson, J., Bryant, R., Taylor, M. D., Harper, W., DeMasi, A., Kyker-Snowman, E. Veremeeva, A., Schirrmeister, L., and Harden, J.: Distribution of late Pleistocene ice-rich syngenetic permafrost of the Yedoma Suite in east and central Siberia, Russia, Geol. Surv. Open File Rep. 2013-1078, available at: http://epic.awi.de/33878/ (last access: 2016), 2013.

Guay, K. C., Beck, P. S. A., Berner, L. T., Goetz, S. J., Baccini, A., and Buermann, W.: Vegetation productivity patterns at high northern latitudes: A multi-sensor satellite data assessment, Glob. Change Biol., 20, 3147-3158, https://doi.org/10.1111/gcb.12647, 2014.

Harden, J. W., Koven, C. D., Ping, C.-L., Hugelius, G., David McGuire, A., Camill, P., Jorgenson, T., Kuhry, P., Michaelson, G. J., O’Donnell, J. A., Schuur, E. A. G., Tarnocai, C., Johnson, K., and Grosse, G.: Field information links permafrost carbon to physical vulnerabilities of thawing, Geophys. Res. Lett., 39, 1-6, https://doi.org/10.1029/2012GL051958, 2012.

Heard, K., Natali, S., Bunn, A., and Alexander, H. D.: Northeast Siberia Plant and Soil Data: Plant Composition and Cover, Plant and Soil Carbon Pools, and Thaw Depth, NSF Arctic Data Center, https://doi.org/10.5065/D6NG4NP0, 2015.

Hobbie, S. E., Schimel, J. P., Trumbore, S. E., and Randerson, J. R.: Controls over carbon storage and turnover in high-latitude soils,
Glob. Change Biol., 6, 196-210, https://doi.org/10.1046/j.13652486.2000.06021.x, 2000.

Hollingsworth, T. N., Schuur, E. A. G., Chapin, F. S., and Walker, M. D.: Plant community composition as a predictor of regional soil carbon storage in Alaskan boreal black spruce ecosystems, Ecosystems, 11, 629-642, https://doi.org/10.1007/s10021-0089147-y, 2008.

Holmes, R. M., McClelland, J. W., Peterson, B. J., Tank, S. E., Bulygina, E., Eglinton, T. I., Gordeev, V. V., Gurtovaya, T. Y., Raymond, P. A., Repeta, D. J., Staples, R., Striegl, R. G., Zhulidov, A. V., and Zimov, S. A.: Seasonal and Annual Fluxes of Nutrients and Organic Matter from Large Rivers to the Arctic Ocean and Surrounding Seas, Estuar. Coast., 35, 369-382, https://doi.org/10.1007/s12237-011-9386-6, 2012.

Hugelius, G., Strauss, J., Zubrzycki, S., Harden, J. W., Schuur, E. A. G., Ping, C.-L., Schirrmeister, L., Grosse, G., Michaelson, G. J., Koven, C. D., O’Donnell, J. A., Elberling, B., Mishra, U., Camill, P., Yu, Z., Palmtag, J., and Kuhry, P.: Estimated stocks of circumpolar permafrost carbon with quantified uncertainty ranges and identified data gaps, Biogeosciences, 11, 6573-6593, https://doi.org/10.5194/bg-11-6573-2014, 2014.

Jean, M. and Payette, S.: Effect of vegetation cover on the ground thermal regime of wooded and non-wooded palsas, Permafrost. Periglac., 25, 281-294, https://doi.org/10.1002/ppp.1817, 2014.

Johnson, K. D., Harden, J., McGuire, A. D., Bliss, N. B., Bockheim, J. G., Clark, M., Nettleton-Hollingsworth, T., Jorgenson, M. T., Kane, E. S., Mack, M., O’Donnell, J., Ping, C. L., Schuur, E. A. G., Turetsky, M. R., and Valentine, D. W.: Soil carbon distribution in Alaska in relation to soil-forming factors, Geoderma, 167-168, 71-84, https://doi.org/10.1016/j.geoderma.2011.10.006, 2011.

Kajimoto, T., Matsuura, Y., Osawa, A., Abaimov, A. P., Zyryanova, O. A., Isaev, A. P., and Yefremov, D. P.: Size - mass allometry and biomass allocation of two larch species growing on the continuous permafrost region in Siberia, Forest Ecol. Manag., 222, 314-325, https://doi.org/10.1016/j.foreco.2005.10.031, 2006.

Kajimoto, T., Osawa, A., Usoltsev, V. A., and Abaimov, A. P.: Biomass and Productivity of Siberian Larch Forest Ecosystems, in Permafrost Ecosystems: Siberian Larch Forests, Vol. 209, edited by: Osawa, A., Zyryanova, O., Matsuura, Y., Kajimoto, T., and Wein, R., 99-120, Springer, New York, 2010.

Kasischke, E. S. and Turetsky, M. R.: Recent changes in the fire regime across the North American boreal region - Spatial and temporal patterns of burning across Canada and Alaska, Geophys. Res. Lett., 33, 1-5, https://doi.org/10.1029/2006GL025677, 2006.

Koven, C. D., Schuur, E. A. G., Schädel, C., Bohn, T. J., Burke, E. J., Chen, G., Chen, X., Ciais, P., Grosse, G., Harden, J. W., Hayes, D. J., Hugelius, G., Jafarov, E. E., Krinner, G., Kuhry, P., Lawrence, D. M., MacDougall, A. H., Marchenko, S. S., McGuire, A. D., Natali, S. M., Nicolsky, D. J., Olefeldt, D., Peng, S., Romanovsky, V. E., Schaefer, K. M., Strauss, J., Treat, C. C., and Turetsky, M.: A simplified, data-constrained approach to estimate the permafrost carbon-climate feedback, Philos. T. R. Soc. A, 373, 20140423, https://doi.org/10.1098/rsta.2014.0423, 2015.

Kurz, W. A., Dymond, C. C., Stinson, G., Rampley, G. J., Neilson, E. T., Carroll, A. L., Ebata, T., and Safranyik, L.: Mountain pine 
beetle and forest carbon feedback to climate change, Nature, 452 , 987-90, https://doi.org/10.1038/nature06777, 2008.

Liljedahl, A. K., Boike, J., Daanen, R. P., Fedorov, A. N., Frost, G. V., Grosse, G., Hinzman, L. D., Iijma, Y., Jorgenson, J. C., Matveyeva, N., Necsoiu, M., Raynolds, M. K., Romanovsky, V. E., Schulla, J., Tape, K. D., Walker, D. A., Wilson, C., Yabuki, H., and Zona, D.: Pan-Arctic ice-wedge degradation in warming permafrost and influence on tundra hydrology, Nat. Geosci., 9, 312-318, https://doi.org/10.1038/ngeo2674, 2016.

Lloyd, A. H.: Ecological Histories from Alaskan Tree Lines Provide Insight into Future Change, Ecology, 86, 1687-1695, 2005.

Loranty, M. M., Berner, L. T., Goetz, S. J., Jin, Y., and Randerson, J. T.: Vegetation controls on northern high latitude snow-albedo feedback: Observations and CMIP5 model simulations, Glob. Change Biol., 20, 594-606, https://doi.org/10.1111/gcb.12391, 2014.

Loranty, M. M., Lieberman-Cribbin, W., Berner, L. T., Natali, S. M., Goetz, S. J., Alexander, H. D., and Kholodov, A. L.: Spatial variation in vegetation productivity trends, fire disturbance, and soil carbon across arctic-boreal permafrost ecosystems, Environ. Res. Lett., 11, 95008, https://doi.org/10.1088/17489326/11/9/095008, 2016.

Mack, M. C., Schuur, E. A. G., Bret-Harte, M. S., Shaver, G. R., and Chapin, F. S.: Ecosystem carbon storage in arctic tundra reduced by long-term nutrient fertilization, Nature, 431, 440-443, https://doi.org/10.1038/nature02887, 2004.

Matsuura, Y. and Hirobe, M.: Soil Carbon and Nitrogen, and Characteristics of Soil Active Layer in Siberian Permafrost Region, in: Permafrost Ecosystems: Siberian Larch Forests, Vol. 209, edited by: Osawa, A., Zyryanova, O., Matsuura, Y., Kajimoto, T., and Wein, R., 149-163, Springer, 2010.

Matsuura, Y., Kajimoto, T., Osawa, A., and Abaimov, A. P.: Carbon storage in larch ecosystems in continuous permafrost region of Siberia, Phyton.-Ann. Rei Bot. A, 45, 51-54, 2005.

Mishra, U. and Riley, W. J.: Alaskan soil carbon stocks: spatial variability and dependence on environmental factors, Biogeosciences, 9, 3637-3645, https://doi.org/10.5194/bg-9-36372012, 2012.

Mishra, U., Jastrow, J. D., Matamala, R., Hugelius, G., Koven, C. D., Harden, J. W., Ping, C. L., Michaelson, G. J., Fan, Z., Miller, R. M., McGuire, A. D., Tarnocai, C., Kuhry, P., Riley, W. J., Schaefer, K., Schuur, E. A. G., Jorgenson, M. T., and Hinzman, L. D.: Empirical estimates to reduce modeling uncertainties of soil organic carbon in permafrost regions: a review of recent progress and remaining challenges, Environ. Res. Lett., 8, 35020, https://doi.org/10.1088/1748-9326/8/3/035020, 2013.

Myers-Smith, I. H., Elmendorf, S. C., Beck, P. S. A., Wilmking, M., Hallinger, M., Blok, D., Tape, K. D., Rayback, S. A., MaciasFauria, M., Forbes, B. C., Speed, J. D. M., Boulanger-Lapointe, N., Rixen, C., Levesque, E., Schmidt, N. M., Baittinger, C., Trant, A. J., Hermanutz, L., Collier, L. S., Dawes, M. A., Lantz, T. C., Weijers, S., Jorgensen, R. H., Buchwal, A., Buras, A., Naito, A. T., Ravolainen, V., Schaepman-Strub, G., Wheeler, J. A., Wipf, S., Guay, K. C., Hik, D. S., and Vellend, M.: Climate sensitivity of shrub growth across the tundra biome, Nat. Clim. Chang., 5, 887-891, https://doi.org/10.1038/nclimate2697, 2015.

Nalder, I. A., Wein, R. W., Alexander, M. E., and de Groot, W. J.: Physical properties of dead and downed round-wood fuels in the boreal forests of Alberta and Northwest Territories, Int. J. Wildl Fire, 27, 1513-1517, https://doi.org/10.1139/x97-083, 1997.

O’Donnell, J. A., Harden, J. W., Mcguire, A. D., Kanevskiy, M. Z., Jorgenson, M. T., and $\mathrm{Xu}, \mathrm{X}$. : The effect of fire and permafrost interactions on soil carbon accumulation in an upland black spruce ecosystem of interior Alaska: Implications for post-thaw carbon loss, Glob. Change Biol., 17, 1461-1474, https://doi.org/10.1111/j.1365-2486.2010.02358.x, 2011.

Osawa, A. and Kajimoto, T.: Development of Stand Structure in Larch Forests, in Permafrost Ecosystems: Siberian Larch Forests, Vol. 209, edited by: Osawa, A., Zyryanova, O., Matsuura, Y., Kajimoto, T., and Wein, R., 123-148, Springer., 2010.

Palmtag, J., Hugelius, G., Lashchinskiy, N., Tamstorf, M. P., Richter, A., Elberling, B., and Kuhry, P.: Storage, landscape distribution, and burial history of soil organic matter in contrasting areas of continuous permafrost, Arctic, Antarct. Alp. Res., 47, 71-88, https://doi.org/10.1657/aaar0014-027, 2015.

Pan, Y., Birdsey, R. A., Fang, J., Houghton, R., Kauppi, P. E., Kurz, W. A., Phillips, O. L., Shvidenko, A., Lewis, S. L., Canadell, J. G., Ciais, P., Jackson, R. B., Pacala, S. W., McGuire, A. D., Piao, S., Rautiainen, A., Sitch, S., and Hayes, D.: A large and persistent carbon sink in the world's forests, Science, 333, 988993, https://doi.org/10.1126/science.1201609, 2011.

Pearson, R. G., Phillips, S. J., Loranty, M. M., Beck, P. S. A., Damoulas, T., Knight, S. J., and Goetz, S. J.: Shifts in Arctic vegetation and associated feedbacks under climate change, Nat. Clim. Chang., 3, 673-677, https://doi.org/10.1038/nclimate1858, 2013.

Pinherio, J., Bates, D., Saikat, D., and Sarkar, D.: nlme: Linear and nonlinear mixed effects models, R package, R-core, 2013.

$\mathrm{R}$ Core Development Team: R: A language and environment for statistical computing, available at: http://www.r-project.org/ (last access: 14 September 2017), 2012.

Rich, P. M., Dubayah, R., Hetrick, W. A., Saving, S. C., and Dubayah, R. O.: Using Viewshed Models to Calculate Intercepted Solar Radiation: Applications in Ecology, Am. Soc. Photogramm. Remote Sens. Tech. Pap., 524-529, 1994.

Rogers, B. M., Soja, A. J., Goulden, M. L., and Randerson, J. T.: Influence of tree species on continental differences in boreal fires and climate feedbacks, Nat. Geosci., 8, 228-234, https://doi.org/10.1016/j.cognition.2008.05.007, 2015.

Salmon, V. G., Soucy, P., Mauritz, M., Celis, G., Natali, S. M., Mack, M. C., and Schuur, E. A. G.: Nitrogen availability increases in a tundra ecosystem during five years of experimental permafrost thaw, Glob. Change Biol., 22, 1927-1941, https://doi.org/10.1111/gcb.13204, 2016.

Schädel, C., Schuur, E. A. G., Bracho, R., Elberling, B., Knoblauch, C., Lee, H., Luo, Y., Shaver, G. R., and Turetsky, M. R.: Circumpolar assessment of permafrost $\mathrm{C}$ quality and its vulnerability over time using long-term incubation data, Glob. Change Biol., 20, 641-652, https://doi.org/10.1111/gcb.12417, 2014.

Schädel, C., Bader, M. K.-F., Schuur, E. A. G., Biasi, C., Bracho, R., Čapek, P., De Baets, S., Diáková, K., Ernakovich, J., EstopAragones, C., Graham, D. E., Hartley, I. P., Iversen, C. M., Kane, E., Knoblauch, C., Lupascu, M., Martikainen, P. J., Natali, S. M., Norby, R. J., O’Donnell, J. A., Chowdhury, T. R., Šantrůčková, H., Shaver, G., Sloan, V. L., Treat, C. C., Turetsky, M. R., Waldrop, M. P., and Wickland, K. P.: Potential carbon emissions dominated by carbon dioxide from thawed permafrost soils, 
Nat. Clim. Chang., 6, 1-5, https://doi.org/10.1038/nclimate3054, 2016.

Schirrmeister, L., Grosse, G., Wetterich, S., Overduin, P. P., Strauss, J., Schuur, E. A. G., and Hubberten, H. W.: Fossil organic matter characteristics in permafrost deposits of the northeast Siberian Arctic, J. Geophys. Res.-Biogeo., 116, G00M02, https://doi.org/10.1029/2011JG001647, 2011.

Schneider von Deimling, T., Grosse, G., Strauss, J., Schirrmeister, L., Morgenstern, A., Schaphoff, S., Meinshausen, M., and Boike, J.: Observation-based modelling of permafrost carbon fluxes with accounting for deep carbon deposits and thermokarst activity, Biogeosciences, 12, 3469-3488, https://doi.org/10.5194/bg12-3469-2015, 2015

Schuur, E. A. G., McGuire, A. D., Grosse, G., Harden, J. W., Hayes, D. J., Hugelius, G., Koven, C. D., and Kuhry, P.: Climate change and the permafrost carbon feedback, Nature, 520, 171-179, https://doi.org/10.1038/nature14338, 2015.

Shmelev, D., Veremeeva, A., Kraev, G., Kholodov, A., Spencer, R. G. M., and Walker, W. S.: Estimation and Sensitivity of Carbon Storage in Permafrost of North-Eastern Yakutia, Permafrost. Periglac., 28, 379-390, https://doi.org/10.1002/ppp.1933, 2017.

Shuman, J. K., Shugart, H. H., and Krankina, O. N.: Assessment of carbon stores in tree biomass for two management scenarios in Russia, Environ. Res. Lett., 8, 1-9, https://doi.org/10.1088/17489326/8/4/045019, 2013.

Siewert, M. B., Hanisch, J., Weiss, N., Kuhry, P., Maximov, T. C., and Hugelius G.: Comparing carbon storage of Siberian tundra and taiga permafrost ecosystems at very high spatial resolution, J. Geophys. Res.-Biogeo., 120, 1973-1994, https://doi.org/10.1002/2015JG002999, 2015.

Soja, A. J., Shugart, H. H., Sukhinin, A., Conard, S., and Stackhouse, P. W.: Satelliet-Derived Mean Fire Return Intervals As Indicators of Change in Siberia (1995-2002), Mitig. Adapt. Strateg. Glob. Chang., 11, 75-96, 2006.

Soja, A. J., Tchebakova, N. M., French, N. H. F., Flannigan, M. D., Shugart, H. H., Stocks, B. J., Sukhinin, A. I., Parfenova, E. I., Chapin, F. S., and Stackhouse, P. W.: Climate-induced boreal forest change: Predictions versus current observations, Global Planet. Change, 56, 274-296, https://doi.org/10.1016/j.gloplacha.2006.07.028, 2007.

Stolbovoi, V.: Soil carbon in the forests of Russia, Mitig. Adapt. Strateg. Glob. Chang., 11, 203-222, https://doi.org/10.1007/s11027-006-1021-7, 2006.

Strauss, J., Schirrmeister, L., Grosse, G., Wetterich, S., U1rich, M., Herzschuh, U., and Hubberten, H. W.: The deep permafrost carbon pool of the Yedoma region in Siberia and Alaska, Geophys. Res. Lett., 40, 6165-6170, https://doi.org/10.1002/2013GL058088, 2013.

Sturm, M., Schimel, J., Michaelson, G., Welker, J. M., Oberbauer, S. F., Liston, G. E., Fahnestock, J., and Romanovsky, V. E.: Winter Biological Processes Could Help Convert Arctic Tundra to Shrubland, Bioscience, 55, 17-26, https://doi.org/10.1641/00063568(2005)055[0017:WBPCHC]2.0.CO;2, 2005.

Swann, A. L., Fung, I. Y., Levis, S., Bonan, G. B., and Doney, S. C.: Changes in Arctic vegetation amplify high-latitude warming through the greenhouse effect, P. Natl. Acad. Sci. USA, 107, 1295-1300, https://doi.org/10.1073/pnas.0913846107, 2010.

Tarnocai, C., Canadell, J. G., Schuur, E. A. G., Kuhry, P., Mazhitova, G., and Zimov, S.: Soil organic carbon pools in the north- ern circumpolar permafrost region, Global Biogeochem. Cy., 23, GB2023, https://doi.org/10.1029/2008GB003327, 2009.

Tautenhahn, S., Lichstein, J. W., Jung, M., Kattge, J., Bohlman, S. A., Heilmeier, H., Prokushkin, A., Kahl, A., and Wirth, C.: Dispersal limitation drives successional pathways in Central Siberian forests under current and intensified fire regimes, Glob. Change Biol., 22, 2178-2197, https://doi.org/10.1111/gcb.13181, 2016.

Ter-Mikaelian, M. T., Colombo, S. J., and Chen, J.: Amount of downed woody debris and its prediction using stand characteristics in boreal and mixedwood forests of Ontario, Canada, Can. J. Forest Res., 38, 2189-2197, https://doi.org/10.1139/X08-067, 2008.

Trahan, M. W. and Schubert, B. A.: Temperature-induced water stress in high-latitude forests in response to natural and anthropogenic warming, Glob. Change Biol., 22, 782-791, https://doi.org/10.1111/gcb.13121, 2016.

Trumbore, S. E. and Harden, J. W.: Accumulation and turnover of carbon in organic and mineral soils of the BOREAS northern study area, J. Geophys. Res., 102, 817-828, 1997.

Turetsky, M. R., Mack, M. C., Hollingsworth, T. N., and Harden, J. W.: The role of mosses in ecosystem succession and function in Alaska's boreal forest, Can. J. Forest Res., 40, 1288-1301, https://doi.org/10.1139/X10-081, 2010.

Ulrich, M., Grosse, G., Strauss, J., and Schirrmeister, L.: Quantifying Wedge-Ice Volumes in Yedoma and Thermokarst Basin Deposits, Permafrost. Periglac., 25, 151-161, https://doi.org/10.1002/ppp.1810, 2014.

Vitharana, U. W. A., Mishra, U., Jastrow, J. D., Matamala, R., and Fan, Z.: Observational needs for estimating Alaskan soil carbon stocks under current and future climate, J. Geophys. Res.Biogeo., 122, 415-429, https://doi.org/10.1002/2016JG003421, 2017.

Walker, X. J., Mack, M. C., and Johnstone, J. F.: Stable carbon isotope analysis reveals widespread drought stress in boreal black spruce forests, Glob. Change Biol., 21, 3102-3113, https://doi.org/10.1111/gcb.12893, 2015.

Walter Anthony, K. M., Zimov, S. A., Grosse, G., Jones, M. C., Anthony, P. M., Iii, F. S. C., Finlay, J. C., Mack, M. C., Davydov, S., Frenzel, P., and Frolking, S.: A shift of thermokarst lakes from carbon sources to sinks during the Holocene epoch, Nature, 511, 452-456, https://doi.org/10.1038/nature13560, 2014.

Wardle, D. A., Nilsson, M. C., Zackrisson, O., and Gallet, C.: Determinants of litter mixing effects in a Swedish boreal forest, Soil Biol. Biochem., 35, 827-835, https://doi.org/10.1016/S00380717(03)00118-4, 2003.

Yoshikawa, K., Bolton, W. R., Romanovsky, V. E., Fukuda, M., and Hinzman, L. D.: Impacts of wildfire on the permafrost in the boreal forests of Interior Alaska, J. Geophys. Res., 108, 16-17, https://doi.org/10.1029/2001JD000438, 2002.

Zimov, S. A., Davydov, S. P., Zimova, G. M., Davydova, A. I., Schuur, E. A. G., Dutta, K., and Chapin, I. S.: Permafrost carbon: Stock and decomposability of a globally significant carbon pool, Geophys. Res. Lett., 33, 1-5, https://doi.org/10.1029/2006GL027484, 2006.

Zuur, A. F., Ieno, E. N., Walker, N. J., Saveliev, A. A., and Smith, G. M.: Mixed Effects Models and Extensions in Ecology with R, Springer, New York, 2009. 